\title{
A Review on Catalysts Development for Steam Reforming of Biodiesel Derived Glycerol; Promoters and Supports
}

\author{
Nasim Ghaffari Saeidabad ${ }^{1,2}$, Young Su Noh ${ }^{1,3}$, Ali Alizadeh Eslami ${ }^{1,2}$, Hyun Tae Song ${ }^{1,2}$, \\ Hyun Dong Kim ${ }^{1,3}{ }^{\mathbb{D}}$, Ali Fazeli ${ }^{1,4}$ and Dong Ju Moon 1,2,3,*(D) \\ 1 Clean Energy Research Center, Korea Institute of Science and Technology (KIST), Seoul 02792, Korea; \\ nasim@kist.re.kr (N.G.S.); ysnoh@kist.re.kr (Y.S.N.); alizadeh.ali@kist.re.kr (A.A.E.); \\ shtcwzz@kist.re.kr (H.T.S.); hdkim99@kist.re.kr (H.D.K.); alifazeli@kist.re.kr (A.F.) \\ 2 Division of Energy \& Environment Technology, KIST School, University of Science and Technology (UST), \\ Seoul 02792, Korea \\ 3 Department of Chemical \& Biological Engineering, Korea University, Seoul 136-713, Korea \\ 4 Department of Chemical Engineering, Caspian Faculty of Engineering, College of Engineering, \\ University of Tehran, P.O. Box 113654563, Tehran, Iran \\ * Correspondence: djmoon@kist.re.kr
}

Received: 14 July 2020; Accepted: 6 August 2020; Published: 10 August 2020

\begin{abstract}
In the last decades, environmental crises and increasing energy demand have motivated researchers to investigate the practical techniques for the production of clean fuels through renewable energy resources. It is essential to develop technologies to utilize glycerol as a byproduct derived from biodiesel. Glycerol is known as a sustainable and clean source of energy, which can be an alternative resource for the production of value-added chemicals and hydrogen. The hydrogen production via steam reforming (SR) of glycerol using Ni-based catalysts is one of the promising approaches for the entry of the hydrogen economy. The purpose of this review paper is to highlight the recent trends in hydrogen production over Ni-based catalysts using the SR of glycerol. The intrinsic ability of $\mathrm{Ni}$ to disperse easily over variable supports makes it a more viable active phase for the SR catalysts. The optimal reaction conditions have been indicated as $650-900{ }^{\circ} \mathrm{C}, 1 \mathrm{bar}$, and $15 \mathrm{wt} \%$ $\mathrm{Ni}$ in catalysts for high glycerol conversion. In this review paper, the effects of various supports, different promoters $(\mathrm{K}, \mathrm{Ca}, \mathrm{Sr}, \mathrm{Ce}, \mathrm{La}, \mathrm{Cr}, \mathrm{Fe})$, and process conditions on the catalytic performance have been summarized and discussed to provide a better comparison for the future works. It was found that $\mathrm{Ce}, \mathrm{Mg}$, and La have a significant effect on catalytic performance as promoters. Moreover, SR of glycerol over hydrotalcite and perovskite-based catalysts have been reviewed as they suggest high catalytic performance in SR of glycerol with improved thermal stability and coke resistance. More specifically, the $\mathrm{Ni} / \mathrm{LaNi}_{0.9} \mathrm{Cu}_{0.1} \mathrm{O}_{3}$ synthesized using perovskite-type supports has shown high glycerol conversion and sufficient hydrogen selectivity at low temperatures. On the other hand, hydrotalcite-like catalysts have shown higher catalytic stability due to high thermal stability and low coke formation. It is vital to notice that the primary concern is developing a high-performance catalyst to utilize crude glycerol efficiently.
\end{abstract}

Keywords: hydrogen production; steam reforming of glycerol; Ni-based catalysts; hydrotalcite; perovskite

\section{Introduction}

Energy demand is inevitably increasing referring the population growth and considering environmental issues such as climate change and air pollution, development of novel technologies for the production of clean fuels is inventible and rapidly increasing. In this regard, hydrogen is a potential clean 
fuel with high energy density and no $\mathrm{CO}_{2}$ emission when burning [1-3]. Furthermore, hydrogen can be used for the production of value-added chemicals such as ammonia, methanol, polyurethane, formic acid, hydrochloric acid, formaldehyde, urea, etc.

This wide demand for hydrogen prompts the development of facile technologies for the production of hydrogen as a key clean component used in many industries [4-6]. Extensive studies are undergoing to implement the hydrogen economy with commercialization vision to achieve a sustainable process. Hydrogen is conventionally produced via the steam reforming (SR) of methane [7]. The SR of methane generally is carried out at a temperature around 800 to $1000{ }^{\circ} \mathrm{C}$, and the main process additionally includes water gas shift reactors and pressure swing adsorption (PSA) for hydrogen purification. The major disadvantages of this process would be $\mathrm{CO}_{2}$ emission, PSA costs, consumption of fossil fuels, and high capital costs [8-11]. Even though hydrogen is a clean fuel, many researchers have still endeavored to find a clean feedstock to substitute fossil fuels for the production of hydrogen. Biodiesel as a fuel owns excellent features such as renewability, lower sulfur content and non-toxicity, biodegradability, and high cetane number, which these properties can serve as a petroleum substitute with increasing market demands in recent years [12]. Crude glycerol is the major by-product (by $10 \mathrm{wt} \%$ ) in biodiesel production, whereas the transesterification of triglycerides, including animal fats, vegetables, and seed oils, is carried out [13-15]. Therefore, the hydrogen production using glycerol is suggested as a sustainable process by which it can utilize the crude glycerol through various pathways such as partial oxidation, steam reforming, and autothermal reforming [10]. Figure 1 illustrates the catalytic reaction of triglycerides with ethanol, whereas glycerol and ethyl esters of fatty acids are produced. Glycerol is mainly used in the pharmaceutical, food industries, and production of various chemicals such as lactic acid, acrolein, citric acid, 1,3-propanediol, antifreeze, and hydrogen [16,17]. Furthermore, the application of such sustainable and cheap resources is more important when we notice that based on the environmental policy in the European Union, biodiesel's use has been considered to grow drastically in the early future [18]. As shown in Figure 2, by implementing different processes, a variety of products can be obtained through the conversion of glycerol. Glycerol is also known as a key chemical building block, and it can be used as a feed for the production of hydrogen via SR of glycerol which is biochemical conversion $[19,20]$.

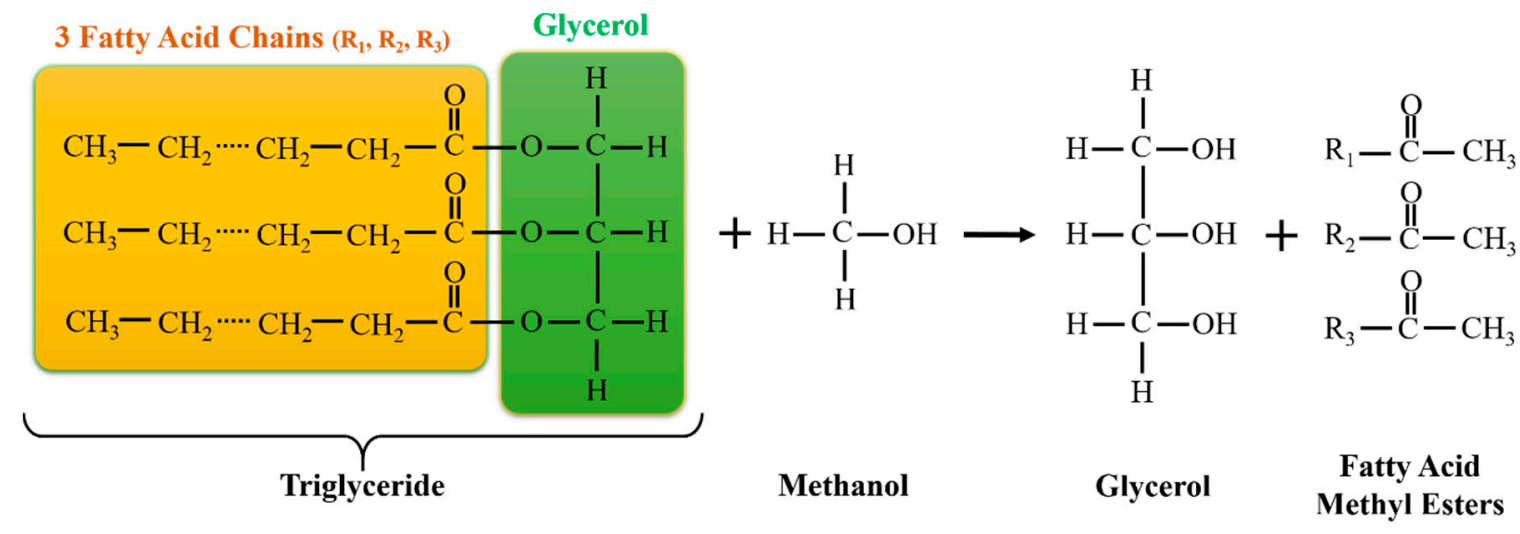

Figure 1. Production of glycerol from the transesterification of triglycerides [20] (redrawn with copyright permission). 


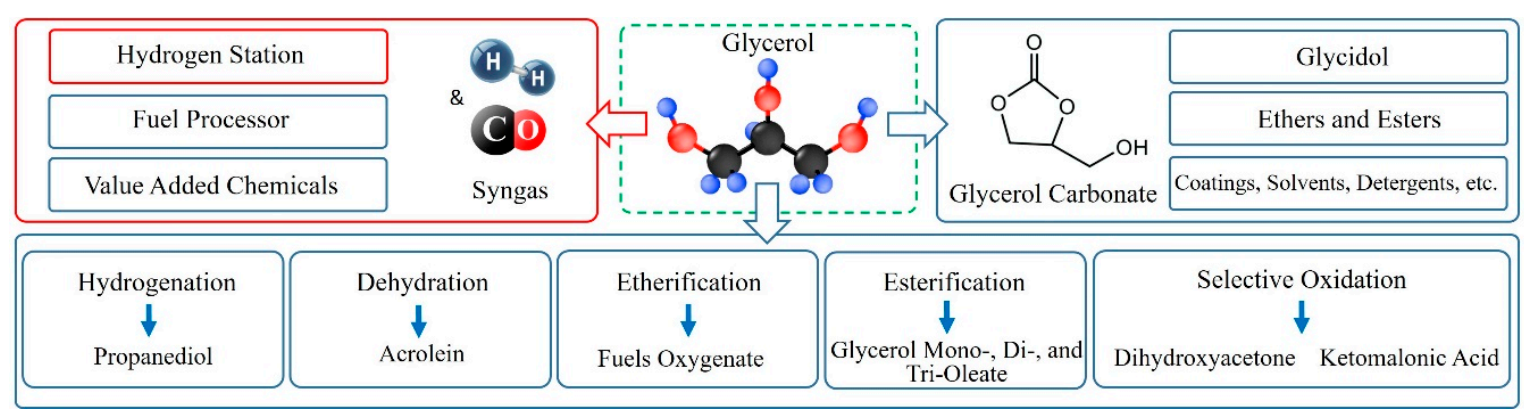

Figure 2. Various products synthesized from glycerol [20] (redrawn with copyright permission).

The hydrogen produced by SR of glycerol is highly dependent on the catalyst, and process conditions. An appropriate catalyst must cleave the $\mathrm{C}-\mathrm{H}, \mathrm{C}-\mathrm{C}$ and $\mathrm{C}-\mathrm{O}$ bonds. Numerous catalysts, including metals: $\mathrm{Pt}, \mathrm{Rh}, \mathrm{Re}, \mathrm{Pd}, \mathrm{Ru}, \mathrm{Ir}, \mathrm{Co}, \mathrm{Cu}$, and $\mathrm{Ni}$ have been studied [21-23]. However, bearing in mind the great costs and short availability of noble metals, practically in the point of commercialization of industrial processes, the development of Ni-based catalysts is more advantageous [24,25]. The main purpose of this paper is to review the evaluation of Ni-based alumina catalysts in the SR of glycerol for the efficient production of hydrogen with an eye on the perovskite-type and hydrotalcite based catalysts.

\section{Perspective of Catalysts}

Generally, the catalyst composition regarding the SR of glycerol typically consists of transition metals such as nickel $(\mathrm{Ni})$ or noble metals such as platinum $(\mathrm{Pt})$, ruthenium $(\mathrm{Ru})$, and palladium (Pd), supported on alumina or perovskite-type catalysts that are doped with promoters to prevent the coke formation. The high costs of the noble metals shifted researchers to substitute them with the low-cost and available metals such as $\mathrm{Ni}$ [26]. Considering the SR of glycerol, C-C, C-H and O-H bond cleavages with conserving the $\mathrm{C}-\mathrm{O}$ bonds are essentially important [27]. The hydrocarbon $(\mathrm{C}-\mathrm{C}, \mathrm{O}-\mathrm{H}$, and $\mathrm{C}-\mathrm{H}$ ) bonds can easily break down in the presence of $\mathrm{Ni}$, with the latter also capable of enhancing the water-gas shift reaction (WGS). Using supports such as aluminum oxide $\left(\mathrm{Al}_{2} \mathrm{O}_{3}\right)$ can lead to improving the metal diffusion, obtaining appropriate acid-base sites, and consequently decreasing the coke deposition on the surface of the catalyst. $\mathrm{Al}_{2} \mathrm{O}_{3}$ is a metal oxide with proper thermal stability and specific surface area [28]. In recent decades, perovskite-type catalysts because of their special crystal structure are more attractive to researchers who focused on the hydrogen economy [29].

The catalytic application of hydrotalcite-like compounds and their derivatives have received extensive attention in the academic and industrial researches. Hydrotalcite-like (HTL) materials are double layered anionic clays with a 2D nanostructure considering the packed arrangement of $\mathrm{OH}$ groups where weak bonding between interlayer anions and structural sheets initiates the ion exchange feature and its physicochemical properties influenced by these anions. Its chemical formula is $\mathrm{Mg}_{6} \mathrm{~A}_{12}(\mathrm{OH})_{16} \mathrm{CO}_{3} 4 \mathrm{H}_{2} \mathrm{O}$, and the double hydroxides are layered. Hydrotalcites usually exist in nature with different forms, such as foliated, contorted plates or fibrous masses [30-32].

\section{Steam Reforming of Glycerol}

In recent years, the SR of glycerol as a process to utilize the crude glycerol obtained from biodiesel production plants has attracted many researchers. The main objective is to produce hydrogen from a renewable biomass resource and furthermore making biodiesel with more economical benefits $[29,33]$. In this review paper, we focused on the SR of glycerol for the efficient production of hydrogen. The SR of glycerol Equation (1), includes glycerol decomposition Equation (2) and water-gas shift reaction Equation (3):

$$
\begin{gathered}
\mathrm{C}_{3} \mathrm{H}_{8} \mathrm{O}_{3}(\mathrm{~g})+3 \mathrm{H}_{2} \mathrm{O}(\mathrm{g}) \leftrightarrow 3 \mathrm{CO}_{2}+7 \mathrm{H}_{2}(\mathrm{~g}) \\
\Delta \mathrm{H}_{25}{ }^{\circ} \mathrm{C}=128 \mathrm{KJ} / \mathrm{mol}
\end{gathered}
$$


The glycerol decomposition:

$$
\begin{aligned}
\mathrm{C}_{3} \mathrm{H}_{8} \mathrm{O}_{3} & \leftrightarrow 3 \mathrm{CO}+4 \mathrm{H}_{2} \\
\Delta \mathrm{H}_{25}{ }^{\circ} \mathrm{C} & =251 \mathrm{KJ} / \mathrm{mol}
\end{aligned}
$$

Water-gas shift reaction (WGS):

$$
\begin{gathered}
\mathrm{CO}+\mathrm{H}_{2} \mathrm{O} \leftrightarrow \mathrm{CO}_{2}+\mathrm{H}_{2} \\
\Delta \mathrm{H}_{25^{\circ} \mathrm{C}}=-41 \mathrm{KJ} / \mathrm{mol}
\end{gathered}
$$

The SR of glycerol may include a couple of secondary reactions, for instance, the methanation, Equations (4) and (5), methane dry reforming, Equation (6), and coke formation, Equations (7)-(10) [34,35]:

$$
\begin{gathered}
\mathrm{CO}+3 \mathrm{H}_{2} \leftrightarrow \mathrm{CH}_{4}+\mathrm{H}_{2} \mathrm{O} \\
\left(\Delta \mathrm{H}_{25}{ }^{\circ} \mathrm{C}=-206 \mathrm{~kJ}\right) \\
\mathrm{CO}_{2}+4 \mathrm{H}_{2} \leftrightarrow \mathrm{CH}_{4}+2 \mathrm{H}_{2} \mathrm{O} \\
\left(\Delta \mathrm{H}_{25}{ }^{\circ} \mathrm{C}=-165 \mathrm{~kJ}\right) \\
\mathrm{CH}_{4}+\mathrm{CO}_{2} \leftrightarrow 2 \mathrm{CO}+2 \mathrm{H}_{2} \\
\left(\Delta \mathrm{H}_{25}{ }^{\circ} \mathrm{C}=247 \mathrm{~kJ}\right) \\
2 \mathrm{CO} \leftrightarrow \mathrm{CO}_{2}+\mathrm{C}(\mathrm{s}) \\
\left(\Delta \mathrm{H}_{25}{ }^{\circ} \mathrm{C}=-172 \mathrm{~kJ}\right) \\
\mathrm{CH}_{4} \rightarrow 2 \mathrm{H}_{2}+\mathrm{C}(\mathrm{s}) \\
\left(\Delta \mathrm{H}_{25}{ }^{\circ} \mathrm{C}=75 \mathrm{~kJ}\right) \\
\mathrm{CO}+\mathrm{H}_{2} \rightarrow \mathrm{H}_{2} \mathrm{O}+\mathrm{C}(\mathrm{s}) \\
\left(\Delta \mathrm{H}_{25}{ }^{\circ} \mathrm{C}=-131 \mathrm{~kJ}\right) \\
\mathrm{CO}_{2}+2 \mathrm{H}_{2} \rightarrow 2 \mathrm{H}_{2} \mathrm{O}+\mathrm{C}(\mathrm{s}) \\
\left(\Delta \mathrm{H}_{25}{ }^{\circ} \mathrm{C}=306 \mathrm{~kJ}\right)
\end{gathered}
$$

It is crucial to notice that in the decomposition of glycerol, methane can be formed as an intermediate. Therefore, a high-performance catalyst which can perform both SR of methane and WGS reaction is needed to produce syngas and convert $\mathrm{CO}$ to $\mathrm{CO}_{2}$, respectively [36].

Coke deposition leads to the catalyst deactivation and is considered as one of the main issues in the SR of glycerol. Therefore, many researchers have investigated developing a durable catalyst and enhanced reaction conditions. In this regard, it was found that the reaction conditions for SR of glycerol generally would be as follows: $700{ }^{\circ} \mathrm{C}, 1$ bar, steam to carbon molar ratio of $\mathrm{H}_{2} \mathrm{O} / \mathrm{C}_{3} \mathrm{H}_{8} \mathrm{O}_{3}=9$ to 12 . It must be noted that the operation at such a high temperature would be tremendously difficult because the glycerol oxygen content is mildly high, and it causes lower thermal stability [37,38]. This fact implies the importance of implementing an efficient catalyst bearing the sintering and avoiding coke formation in the process. In other words, in the catalytic SR of glycerol, the development of a high-performance catalyst is an important factor for the commercialization of this process [39].

Many researchers have studied the effect of synthesis methods of the catalyst with modified supports $\left(\mathrm{MgO}, \mathrm{CeO}_{2}, \mathrm{Al}_{2} \mathrm{O}_{3}\right.$, and $\mathrm{TiO}_{2}$ ) and promoters (using various transition metals including $\mathrm{Co}, \mathrm{Cu}, \mathrm{Zr}, \mathrm{Ce}, \mathrm{Rh}, \mathrm{Ru}, \mathrm{Pt}$ and $\mathrm{Pd}$, and $\mathrm{Fe}$ ) to obtain high yields [40-42]. Ming et al. [43] reported that when using bare alumina as a catalyst, the hydrogen yield was $39 \%$. However, when the catalyst was modified as $\mathrm{Ni} / \mathrm{Al}_{2} \mathrm{O}_{3}, \mathrm{Co} / \mathrm{Al}_{2} \mathrm{O}_{3}$, and $\mathrm{La} / \mathrm{Al}_{2} \mathrm{O}_{3}$, these yields reached $47.7,43.8$, and $54.5 \%$, respectively. The $\mathrm{Ni} / \mathrm{La} / \mathrm{Co} / \mathrm{Al}_{2} \mathrm{O}_{3}$ catalyst showed the highest hydrogen yield, $77.7 \%$. Kousi et al. [44] stated that the enhanced activity and high hydrogen yield in the SR of glycerol could be achieved by introducing 
$\mathrm{La}_{2} \mathrm{O}_{3}$ as a promoter to the $\mathrm{Ni} / \mathrm{Al}_{2} \mathrm{O}_{3}$ catalyst. Table 1 listed a summary of process conditions for the $\mathrm{SR}$ of glycerol over Ni-based catalysts.

Table 1. Summary of process conditions for Ni-based glycerol steam reforming.

\begin{tabular}{|c|c|c|c|c|c|c|c|}
\hline $\mathrm{T}\left({ }^{\circ} \mathrm{C}\right)$ & P (Bar) & $\begin{array}{c}\mathrm{H}_{2} \mathrm{O} / \mathrm{C}_{3} \mathrm{H}_{8} \mathrm{O}_{3} \\
\text { Molar Ratio }\end{array}$ & Support & Promoters & Ni Content wt $\%$ & $\begin{array}{c}\text { Glycerol } \\
\text { Conversion (\%) }\end{array}$ & Ref. \\
\hline 500,650 & 1 & 3.7 & $\mathrm{La}_{2} \mathrm{O}_{3}-\mathrm{ZrO}_{2}$ & - & 15 & 99.9 & [45] \\
\hline $400 \sim 800$ & & 3 & $\mathrm{CaO}-\mathrm{ATP}^{*}$ & - & 10 & 93.7 & [46] \\
\hline 650 & 1 & 3.7 & $\mathrm{CeO}_{2}-\mathrm{ZrO}_{2}$ & $\mathrm{La}$ & 12 & 99.9 & [47] \\
\hline $550 \sim 650$ & - & 9 & Graphene & - & $13 \sim 14.7$ & 95.1 & [48] \\
\hline 600 & 1 & 12 & $\mathrm{Al}_{2} \mathrm{O}_{3} / \mathrm{Al}_{2} \mathrm{O}_{4}$ & - & 15 & 99.0 & [49] \\
\hline $450 \sim 550$ & 1 & $8 \sim 14$ & Fly ash & - & $2.5,5,7.5,10$ & 96.0 & [50] \\
\hline 400 750 & 1 & 2.6 & $\mathrm{Al}_{2} \mathrm{O}_{3}, \mathrm{La}_{2} \mathrm{O}_{3}$ & & 8 & 70 92.0 & [51] \\
\hline $500 \sim 650$ & 1 & 3.7 & $\mathrm{TiO}_{2}$ & La & 15 & 99.7 & [52] \\
\hline 650 & - & 3 & $\mathrm{ZrO}_{2}$ & $\mathrm{Pr}, \mathrm{Ce}, \mathrm{La}, \mathrm{Yb}$ & 20 & 90 & [53] \\
\hline 650 & 1 & $6 \sim 15$ & $\mathrm{CeO}_{2}, \mathrm{Al}_{2} \mathrm{O}_{3}, \mathrm{SiO}_{2}$ & - & 15 & 92 & [54] \\
\hline 650 & - & 12 & $\mathrm{SiO}_{2}$ & $\mathrm{Mg}$ & 10 & 91 97.0 & [55] \\
\hline 700 & 1 & 5 & Zeolite $\mathrm{Y} / \mathrm{CeO}_{2}$ & $\mathrm{Cs}$ or $\mathrm{Na}$ & 13 & 99.0 & [56] \\
\hline 400 700 & - & 9 & $\mathrm{ZrO}_{2}$ & - & 5 & 98.0 & [57] \\
\hline 630 & 1 & 9 & $\mathrm{NiAl}_{2} \mathrm{O}_{4}$ & - & - & 88.2 & [58] \\
\hline 500 & - & 4 & $\mathrm{Al}_{2} \mathrm{O}_{3}, \mathrm{AlCeO}_{3}$ & $\mathrm{CaO}$ & 20 & 95.0 & [59] \\
\hline
\end{tabular}

\section{The Effect of Support in SR of Glycerol over Ni-Based Catalysts}

The effect of support was discussed concerning the glycerol conversion and $\mathrm{H}_{2}$ selectivity in the $\mathrm{SR}$ of glycerol using various Ni-based catalysts. The interaction of the metal with support is a crucial parameter that influences the catalytic activity and the coke formation.

In order to decrease the coke deposition and improve catalytic activity, $\mathrm{MgO}, \mathrm{CeO}_{2}$, and $\mathrm{TiO}_{2}$ have been used as supports that provide sufficient interaction with metals [60]. Buffoni et al. [61] investigated the effect of $\mathrm{ZrO}_{2}$ and $\mathrm{CeO}_{2}$ addition to the commercial $\alpha-\mathrm{Al}_{2} \mathrm{O}_{3}$. According to Figure 3, the $\mathrm{Ni} / \mathrm{CeO}_{2} / \mathrm{Al}_{2} \mathrm{O}_{3}$ catalyst exhibited better catalytic stability with glycerol conversion of $90 \%$ and an $\mathrm{H}_{2}$ yield of $86 \%$. The role of $\mathrm{Ce}$ as an inhibitor to prevent the secondary dehydration reactions was proved.
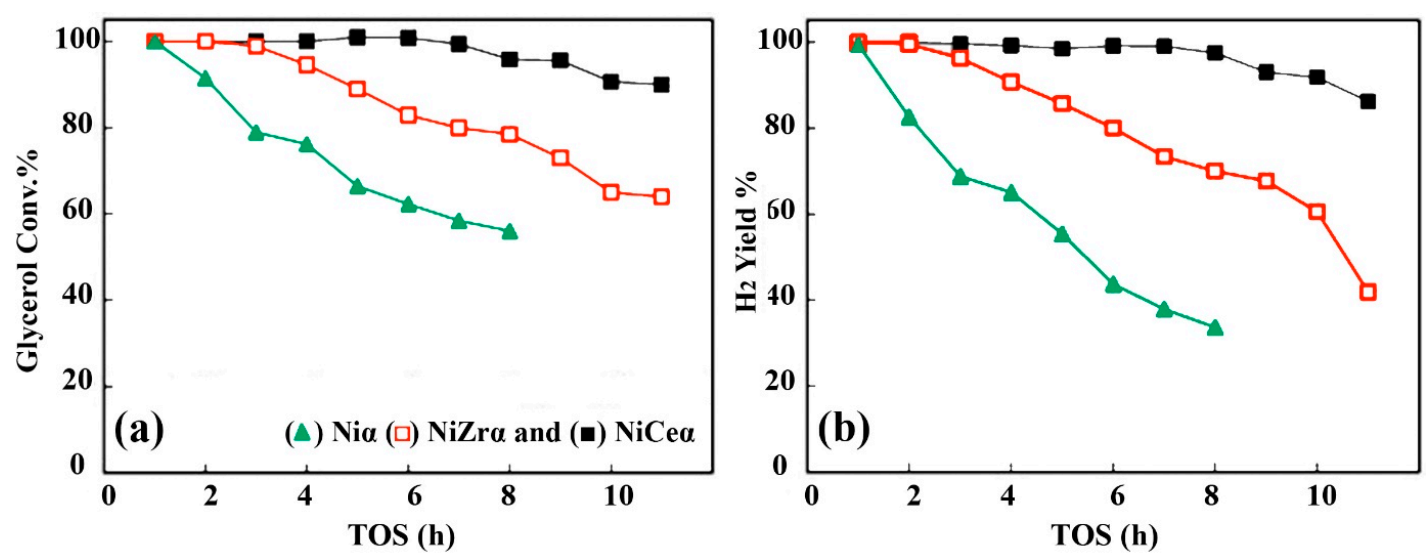

Figure 3. Stability tests at $600{ }^{\circ} \mathrm{C}$ of the studied catalysts, (a) glycerol conversion, and (b) $\mathrm{H}_{2}$ yield \% [61] (redrawn with copyright permission).

Moon et al. [62] investigated $\mathrm{Ni}$ catalysts supported on $\mathrm{Al}_{2} \mathrm{O}_{3}-\mathrm{SiO}_{2}$ in terms of $\mathrm{Ni}$ content and the role of the support, $\mathrm{SiO}_{2}(0,5,70 \mathrm{wt} \%)$ The result has shown that $15 \%$ of $\mathrm{Ni}$ is the optimum amount of nickel for high glycerol conversion (Table 2). It was found that $\mathrm{Ni} / \mathrm{SiO}_{2}(70)-\mathrm{Al}_{2} \mathrm{O}_{3}$ catalyst with a high surface area enhanced the catalytic activity. This could be due to the ability of this catalyst to reduce $\mathrm{NiO}$ to $\mathrm{Ni}$ easily and prevent the formation of $\mathrm{NiAl}_{2} \mathrm{O}_{4}$. 
Table 2. Results of the reaction performance for steam reforming (SR) of glycerol using 15\% Ni-based catalysts [62].

\begin{tabular}{|c|c|c|c|c|c|c|}
\hline \multirow{2}{*}{ Catalyst } & \multirow{2}{*}{$\mathrm{T}\left({ }^{\circ} \mathrm{C}\right)$} & \multirow{2}{*}{ Glycerol Conversion (\%) } & \multirow{2}{*}{$\mathrm{H}_{2}$ Selectivity $(\%)$} & \multicolumn{3}{|c|}{ C1 Electivity (\%) } \\
\hline & & & & $\mathrm{CO}$ & $\mathrm{CH}_{4}$ & $\mathrm{CO}_{2}$ \\
\hline \multirow{4}{*}{$\mathrm{Ni} / \mathrm{Al}_{2} \mathrm{O}_{3}$} & 350 & 74.1 & 33.5 & 77.8 & 0.2 & 21.9 \\
\hline & 450 & 99.2 & 83.2 & 28.6 & 2.3 & 69.1 \\
\hline & 550 & 100 & 87.3 & 20.6 & 6.7 & 72.7 \\
\hline & 350 & 82.7 & 39.7 & 79.1 & 0.9 & 20.0 \\
\hline \multirow{3}{*}{$\mathrm{Ni} / \mathrm{SiO}_{2}(5)-\mathrm{Al}_{2} \mathrm{O}_{3}$} & 450 & 91.9 & 83.4 & 25.4 & 3.5 & 71.2 \\
\hline & 550 & 100 & 85.9 & 21.3 & 6.9 & 71.8 \\
\hline & 350 & 99.7 & 36.6 & 89.4 & 1.4 & 9.3 \\
\hline \multirow[t]{2}{*}{$\mathrm{Ni} / \mathrm{SiO}_{2}(70)-\mathrm{Al}_{2} \mathrm{O}_{3}$} & 450 & 100 & 58.7 & 45.1 & 13.1 & 41.9 \\
\hline & 550 & 100 & 75.3 & 19.4 & 13.9 & 66.6 \\
\hline
\end{tabular}

In another research, Menezes et al. [63] studied the Ni catalysts supported on alumina, niobia, and the combination of these two supports as $10 \mathrm{wt} \% \mathrm{Ni}$ supported on niobia/alumina. Niobia plays a crucial role in improving the Ni dispersion and consequently decreasres the coke deposition. Figure 4 shows the catalytic performance results in the SR of glycerol over the synthesized catalysts at $500{ }^{\circ} \mathrm{C}$ for $30 \mathrm{~h}$. It was found that the $\mathrm{Ni} / \mathrm{Nb}_{2} \mathrm{O}_{5}-\mathrm{Al}_{2} \mathrm{O}_{3}$ catalyst exhibited higher glycerol conversion and hydrogen yield about 80 and $50 \%$, respectively. Bastan et al. [64] prepared a series of nanostructured $\mathrm{Ni} / \mathrm{X}$ catalysts $\left(\mathrm{X}=\mathrm{Al}_{2} \mathrm{O}_{3}, \mathrm{MgO}\right.$, and $\left.\mathrm{MgO}-\mathrm{Al}_{2} \mathrm{O}_{3}\right)$ via the co-precipitation method. It was declared that the $\mathrm{Ni} \mathrm{MgO}-\mathrm{Al}_{2} \mathrm{O}_{3}$ had shown better catalytic performance in SR of glycerol.
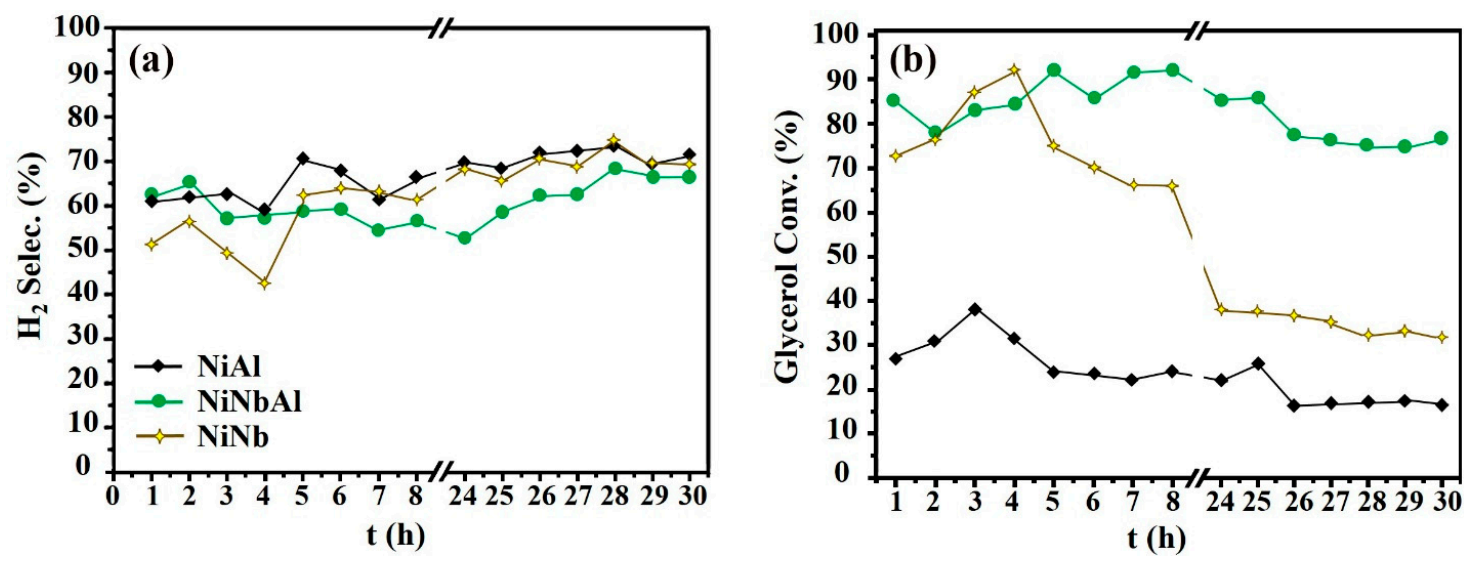

Figure 4. (a) $\mathrm{H}_{2}$ selectivity and (b) glycerol conversion into gas [63] (redrawn with copyright permission).

The carbon nanotubes (CNTs) exhibited several outstanding physicochemical properties such as significant electron conductivity, proper mechanical strength, and a porous structure with a high surface area. Therefore, these materials have been considered with numerous applications specifically as support in heterogeneous catalysis. The important feature of using CNTs in catalytic reactions is the possibility to modify the chemical composition and functionalization of the surface, which these improvements lead to sufficient interactions between the metal and support [65-68]. Shuzhuang et al. [65] suggested that Ni (15\%) supported on the CNT could demonstrate high catalytic activity owning $86.4 \%$ of glycerol conversion for gaseous products with $72.9 \%$ for the hydrogen selectivity at low temperature $\left(375{ }^{\circ} \mathrm{C}\right)$. This observation could be due to improved reducibility, enhanced thermal conductivity, and better active phase dispersion. Santiago et al. [28] studied the SR of glycerol over activated carbon and used various metal oxides such as $\mathrm{MgO}, \mathrm{La}_{2} \mathrm{O}_{3}$, and $\mathrm{Y}_{2} \mathrm{O}_{3}$ as the promoter. It was found that the catalyst promoted with $\mathrm{Mg}$ as $\mathrm{NiMg} / \mathrm{AC}-\mathrm{OX}$ showed higher $\mathrm{Ni}$ dispersion, which led to a better catalytic performance (Figure 5). Furthermore, a lower amount of the methane in the product distribution reveals that as expected, the SR mechanism performed well in this catalyst [28]. 


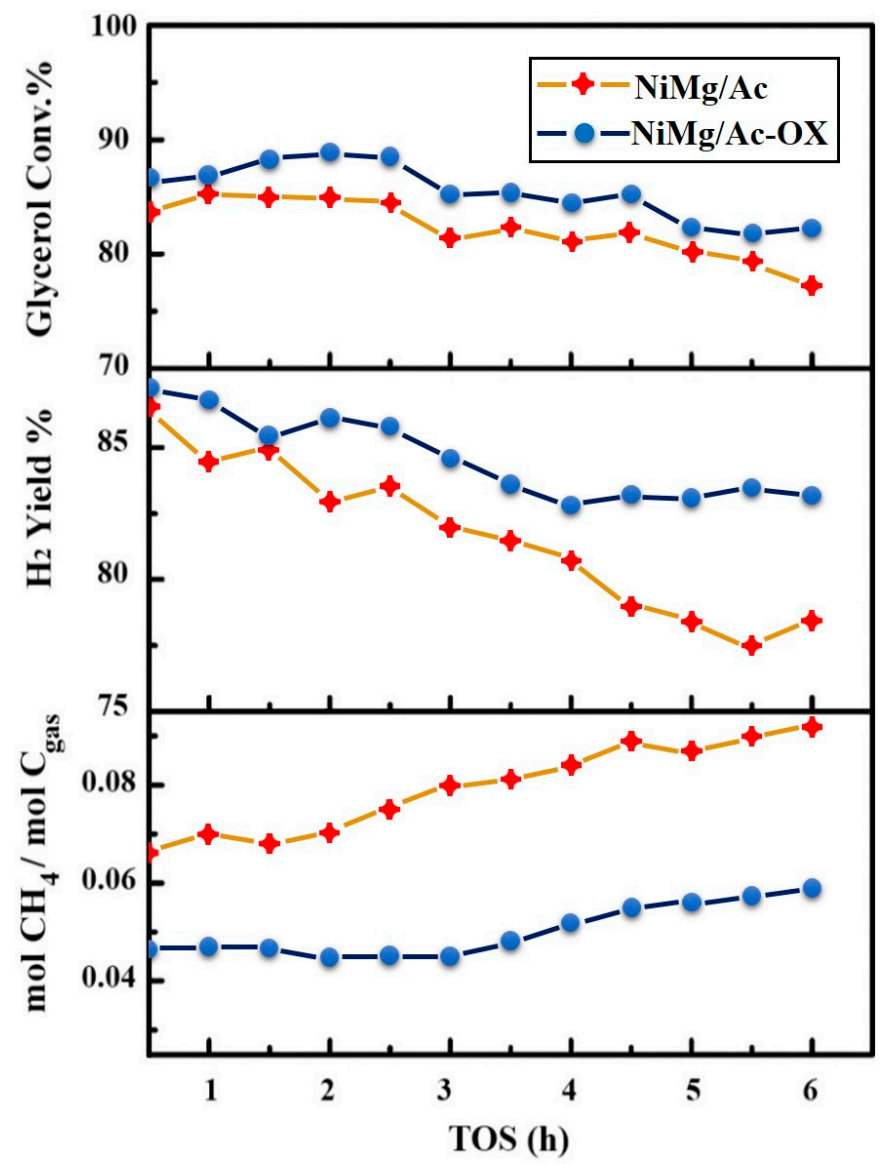

Figure 5. Over $\mathrm{NiMg} / \mathrm{AC}$ and $\mathrm{NiMg} / \mathrm{AC}-\mathrm{OX}$ catalysts at $650{ }^{\circ} \mathrm{C}$ [28] (redrawn with copyright permission).

\section{The Effect of Promoters in SR of Glycerol over Ni-Based Catalyst}

The major drawback of the Ni-based catalysts is catalyst deactivation through sintering and coke formation. This issue causes side reactions as well. Using various promoters (e.g., noble or transition metals) has been suggested to overcome this issue through enhancement of catalytic stability [69]. Araque et al. [70] reported that the condensable molecules such as acrolein, acetaldehyde, and hydroxyacetone can be obtained through the SR of glycerol, which can mainly initiate the coke formation. It is mentioned that ethylene is also known as a coke precursor. Frusteri et al. [71] showed that ethanol hydration was suppressed by using basic promoters, and consequently, the ethylene formation was decreased. It was concluded that the alkaline promoters would have a similar effect as the hydration process in the SR of glycerol. Iriondo et al. [72] investigated the addition of $\mathrm{Ce}, \mathrm{Zr}$, and $\mathrm{La}$ as promoters to Ni-based alumina catalysts. The addition of promoters showed enhancement in the hydrogen selectivity; however, each promoter would have a different effect in the reaction mechanism. For instance, it was found that strong $\mathrm{Ni}-\mathrm{ZrO}_{2}$ interactions would occur, but on the other hand, introducing $\mathrm{Zr}$ to alumina support lowers $\mathrm{Ni}$ dispersion as well.

Furthermore, Ce and La could boost the catalytic stability in terms of resistance to the coke deposition. Gallegos and et al. [73] investigated the Ni-Ce-based catalysts for the SR of glycerol (10 $\mathrm{wt} \%$ $\mathrm{C}_{3} \mathrm{H}_{8} \mathrm{O}_{3}$ in water). As a result, the catalyst with $20 \mathrm{~mol} \%$ of nickel content among other Ni-Ce catalysts showed the optimum ratio that could minimize $\mathrm{CO}$ and $\mathrm{CH}_{4}$ as two major byproducts.

In other research, Demsash et al. [74] studied Ni-based catalysts promoted with Ce in different loadings of $\mathrm{Ni}(5,10,15 \mathrm{wt} \%)$, and $\mathrm{Ce}(5,10 \mathrm{wt} \%)$. Ce: $\mathrm{Ni} \mathrm{Al}_{2} \mathrm{O}_{3}=5: 10: 100$ was selected as the optimum loading with sufficient catalytic activity and stability over $16 \mathrm{~h}$. The glycerol conversion and hydrogen selectivity were reported to 86 and $96 \%$ at $650{ }^{\circ} \mathrm{C}$, respectively. In another work, Shao et al. [38] studied the $\mathrm{Ni} / \mathrm{CeZrO}$ catalysts with different Ce content. They declared that at higher contents of Ce up to 
$77 \mathrm{wt} \%$, the BET surface area was maximized and showed high enhanced catalytic activity in the SR of glycerol. Moon et al. [75], also investigated the effect of cerium on the $\mathrm{Ni}-\mathrm{Fe} / \mathrm{Al}_{2} \mathrm{O}_{3}$ catalyst, and the obtained results were listed in Table 3.

Cerium and iron as two efficient prompters increased the reducibility of the Ni-based catalysts. Therefore, the active sites of the $\mathrm{NiFeCeAl}$ catalyst were reduced easily than those of the other catalysts. Moreover, cerium decreased sintering and coke deposition [75].

Lukman et al. [76], studied the production of hydrogen through the SR of glycerol over $\mathrm{Ni}-\mathrm{Ce}-\mathrm{Cu} / \mathrm{hydroxyapatite}$ catalysts. The catalyst with the composition of $\mathrm{Ni}: \mathrm{Ce}: \mathrm{Cu}=3: 7.5: 7.5 \mathrm{wt} \%$ showed a high glycerol conversion and hydrogen yield of 97 and $57 \%$, respectively.

Sanchez et al. [77] studied the addition of $\mathrm{La}$ on the $\mathrm{Ni} / \mathrm{Al}_{2} \mathrm{O}_{3}$ catalyst for SR of glycerol. The results showed that the addition of La led to an increase in the surface area and decreased the coke formation. The $\mathrm{Ni} / \mathrm{La}_{2} \mathrm{O}_{3} / \mathrm{Al}_{2} \mathrm{O}_{3}$ catalyst exhibited enhanced catalytic stability during the SR of glycerol. Furthermore, it was expected that La could also influence the Ni particle distribution and, consequently, decrease the sintering of active sites through stronger metal support interactions. Chao Wang et al. [78] suggested the addition of $\mathrm{CaO}$ to the Ni-based alumina catalyst as a multifunctional catalyst for $\mathrm{SR}$ of glycerol and the subsequently $\mathrm{CO}_{2}$ sorbent unit. The catalytic performance tests for SR of glycerol were performed at $550{ }^{\circ} \mathrm{C}$ and $\mathrm{H}_{2} \mathrm{O} / \mathrm{C}_{3} \mathrm{H}_{8} \mathrm{O}_{3}$ molar ratio of 9 as multi cycles with regeneration processes. It was found that the catalyst with the composition of $\mathrm{NiO}: \mathrm{CaO}: \mathrm{Al}_{2} \mathrm{O}_{3}=41.21: 30.77: 28.02 \mathrm{wt} \%$ showed high-purity hydrogen.

Bobadilla et al. [79] studied the effect of Ni-Sn alloying in the SR of glycerol over the promoted $\mathrm{Ni}-\mathrm{Sn} / \mathrm{CeMgAl}$ catalyst. Based on the SEM images of the fresh and used catalysts (Figure 6), it was observed that the growth of filamentous carbons on the surface of the Sn promoted catalyst was decreased. This phenomenon can be due to the core-shell system, whereas a layer of Sn clusters surrounds Ni. The adsorption capacity of the glycerol on the active sites was also enhanced, and the bimetallic configuration of $\mathrm{Ni}$ and $\mathrm{Sn}$ in the $\mathrm{Ni}-\mathrm{Sn} / \mathrm{CeMgAl}$ catalyst exhibited a better catalytic activity and durability.

Oemar et al. [80] studied the addition of $\mathrm{Sr}$ to $\mathrm{Ni} / \mathrm{La}_{2} \mathrm{O}_{3}$ catalyst via co-impregnation and sequential impregnation methods for the SR of toluene. They showed that besides the positive effect of Sr as a promoter on the enhancement of catalytic activity, the preparation method and sequences of the $\mathrm{Sr}$ addition are also important. $\mathrm{Ni}-\mathrm{Sr} / \mathrm{La}_{2} \mathrm{O}_{3}$ (NSL) and $\mathrm{Sr} / \mathrm{Ni} / \mathrm{La}_{2} \mathrm{O}_{3}$ (SNL) catalysts showed different performances, whereas a higher catalytic activity was attributed to the SNL. It is important to notice that $\mathrm{Sr}$ in the SNL catalyst has a weaker interaction with Ni particles; however in the case of NSL, the Sr seems to be placed between $\mathrm{La}_{2} \mathrm{O}_{3}$ and $\mathrm{Ni}$, and somehow influenced their electronic states. A similar approach can be investigated for the SR of glycerol.

Calles et al. [81] investigated the promoter effect of $\mathrm{Mg}$ and Ca on Ni-based SBA-15 catalysts in SR of glycerol at $600{ }^{\circ} \mathrm{C}$. The glycerol conversion and hydrogen yield of $98 \%$ were observed for the Ni/Ca/SBA- 15 catalyst. Figure 7 shows that the Ca has decreased the Ni particle size over the SBA-15 support and enhanced the catalytic performance compared to the bare sample of Ni/Ca/SBA- 15 . Narrow sized Ni particles could provide stronger interactions with the support, which can improve the coke resistance feature of the catalyst. It is believed that the presence of structural defective carbon deposits facilitates the gasification process and avoids the formation of encapsulated filamentous carbon. Choong et al. [82] also confirmed that the addition of $\mathrm{Mg}$ and $\mathrm{Ca}$ can improve the catalytic performance through the activation of water adsorption which eventually facilitates the steam gasification of deposited coke on the catalyst surface.

Moon et al. [83] studied the alkali metals (Ca, Sr, and K) promoted Ni-based catalysts in SR of glycerol. The catalysts were prepared via the dry impregnation method at various calcination temperatures $\left(750,850\right.$, and $950^{\circ} \mathrm{C}$ corresponding to $\mathrm{A}, \mathrm{B}$, and $\mathrm{C}$, respectively), and Ni loading was kept at $15 \mathrm{wt} \%$, and $\mathrm{Ca}, \mathrm{Sr}$, and $\mathrm{K}$ loadings were $1 \mathrm{wt} \%$, respectively. Table 4 shows the physicochemical properties of the synthesized promoted Ni-based catalysts. 

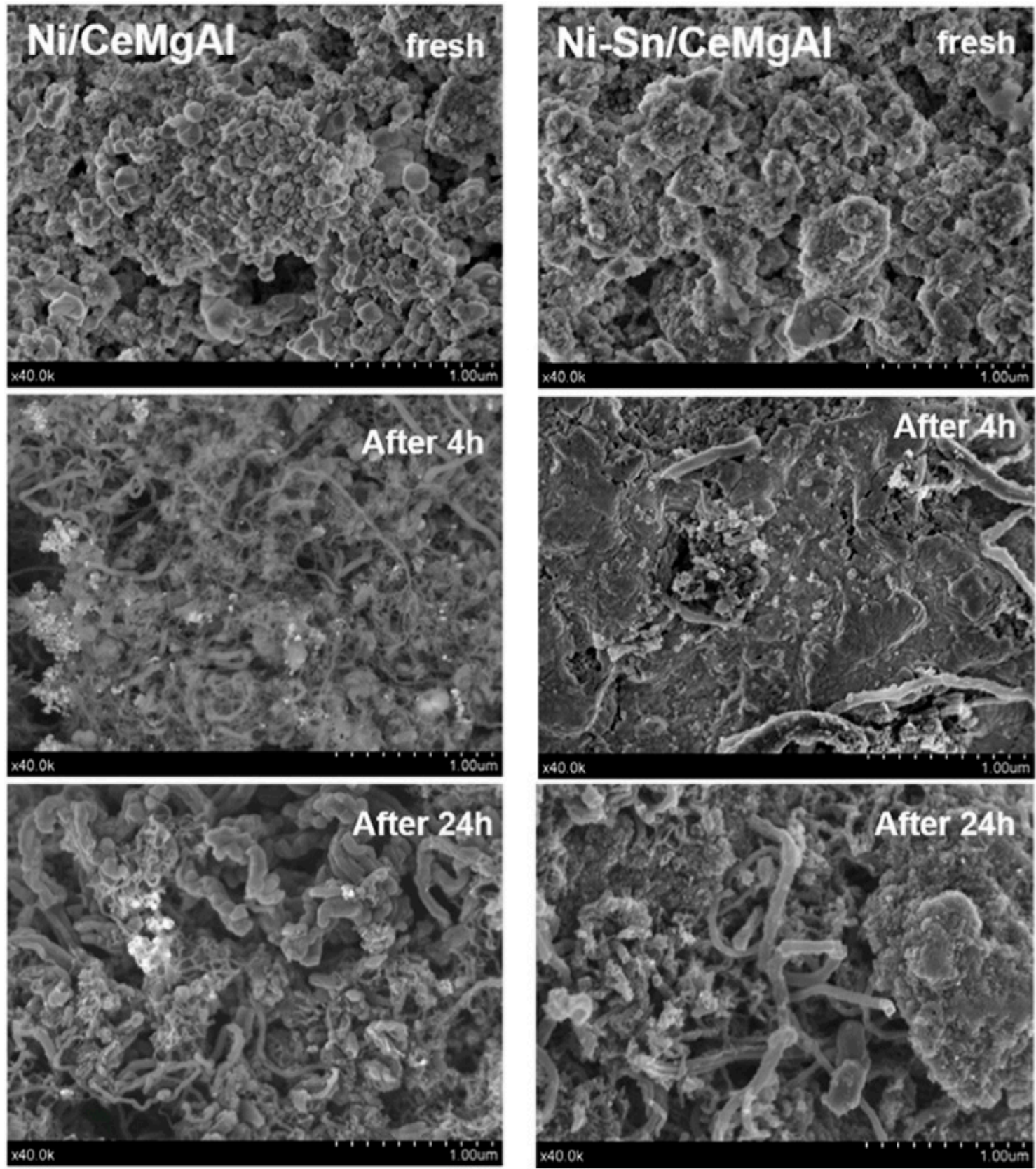

Figure 6. SEM images of fresh and used $\mathrm{Ni} / \mathrm{CeMgAl}$ and $\mathrm{Ni}-\mathrm{Sn} / \mathrm{CeMgAl}$ catalysts in SR of glycerol at $750{ }^{\circ} \mathrm{C}[79]$ (used with copyright permission).

It was observed that the BET surface area and pore volume of the catalysts were reduced at higher calcination temperature, while the particle growth is also indicated. At high calcination temperatures, the phase transition of $\mathrm{Al}_{2} \mathrm{O}_{3}$ support from $\gamma$ to $\delta$ or the $\theta$ phase is more probable which can be the main reason for the morphology change of the catalyst as well. Moreover, this change in the morphology can be interpreted to the addition of alkali promoters as it was expected to observe bigger catalyst particles.

The addition of promoters can also lead to the plugging of the pore cavities of the support. The results of catalytic performance test for the SR of glycerol over the prepared catalysts are listed in Table 5. In the case of the catalysts that were calcinated at higher temperatures, the methane selectivity and coke formation were reduced, but the conversion and hydrogen selectivity were almost constant. 


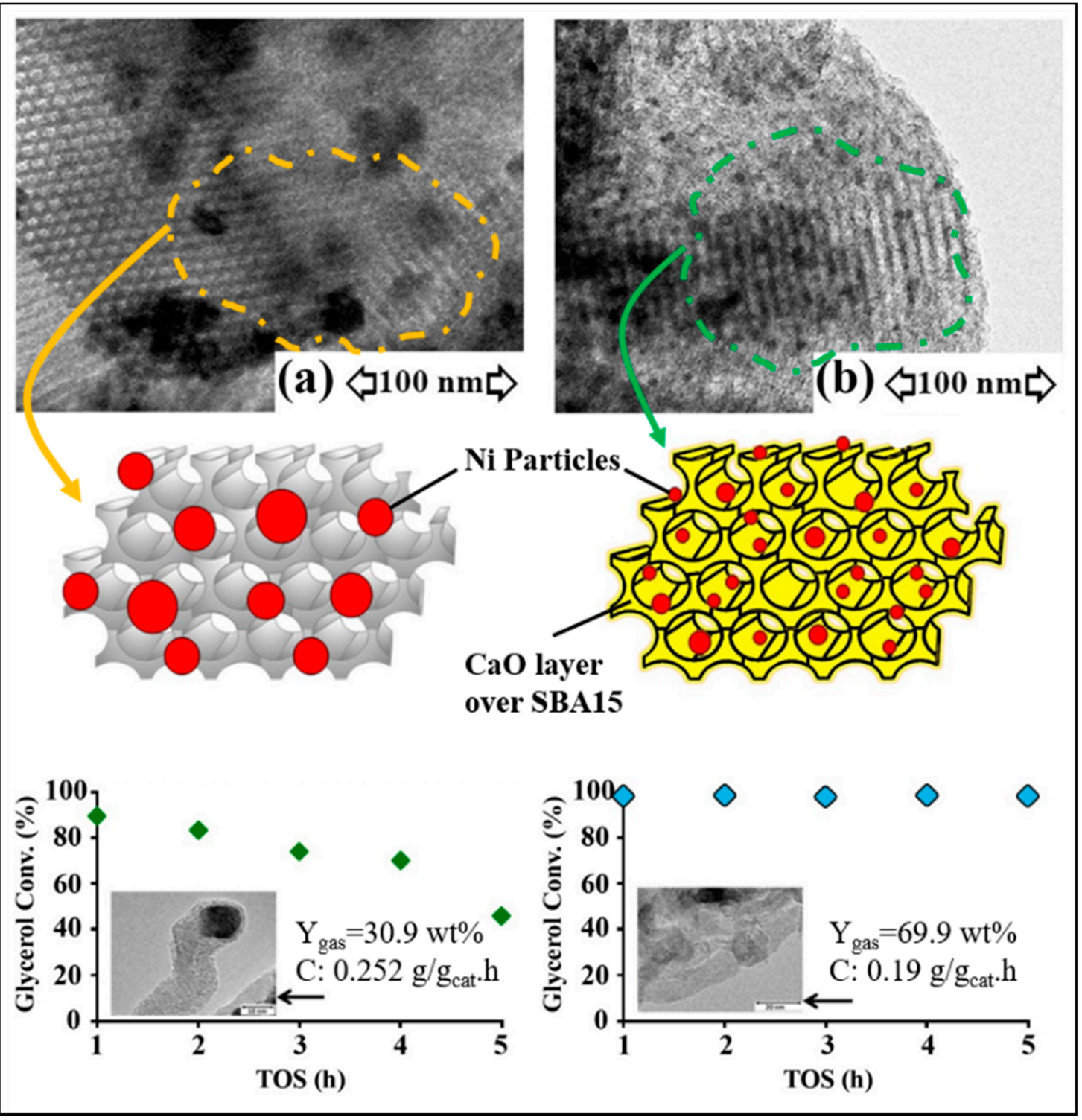

Figure 7. The catalytic glycerol conversion over (a) Ni/SBA-15, and (b) Ni/Ca/SBA-15 catalysts; the effect of Ni particle size [81] (redrawn with copyright permission).

Araque et al. [70] reported that the condensable molecules such as acrolein, acetaldehyde, and hydroxyacetone could be obtained through the SR of glycerol, which can mainly initiate the coke formation. It is mentioned that ethylene is also known as a coke precursor. Frusteri et al. [71] showed that by using basic promoters, ethanol hydration is suppressed, and ethylene formation was decreased. Hence, there is a possibility that the alkaline promoters will have the same impact as the hydration process in the SR of glycerol. 
Table 3. Catalytic performance results for $\mathrm{SR}$ of glycerol over the Fe and Ce promoted $\mathrm{Ni} / \mathrm{Al}_{2} \mathrm{O}_{3}$ catalyst [75].

\begin{tabular}{cccccc}
\hline \multirow{2}{*}{ Catalyst } & \multirow{2}{*}{ Glycerol Conversion (\%) } & \multirow{2}{*}{$\mathbf{H}_{\mathbf{2}}$ Selectivity (\%) } & \multicolumn{3}{c}{$\mathrm{C}_{\mathbf{1}}$ Product Selectivity (\%) } \\
\cline { 3 - 6 } & & & $\mathrm{CO}$ & \multicolumn{2}{c}{$\mathbf{C H}_{\mathbf{4}}$} \\
\hline $\mathrm{NiAl}$ & 81 & 63 & 2.3 & 2.7 & $\mathbf{C O}_{\mathbf{2}}$ \\
$\mathrm{NiFeAl}$ & 89 & 63 & 2.0 & 2.2 & 31.8 \\
$\mathrm{NiFeCeAl}$ & 94 & 64 & 1.3 & 2.2 & 32.1 \\
\hline
\end{tabular}

Reaction Cond.: $\mathrm{T}=450{ }^{\circ} \mathrm{C}, 20 \mathrm{wt} \%$ glycerol, and GHSV $=7300 \mathrm{~mL} /$ gcat $\cdot \mathrm{h}$.

Table 4. The physicochemical properties of alkali promoted Ni-based catalysts [83] (used with copyright permission).

\begin{tabular}{|c|c|c|c|c|c|c|}
\hline \multirow{2}{*}{ Catalyst } & \multirow{2}{*}{ Calcination Temp. $\left({ }^{\circ} \mathrm{C}\right)$} & \multirow{2}{*}{ Pore Volume (cc/g) } & \multicolumn{2}{|c|}{ Particle Size (nm) } & \multirow{2}{*}{ BET Surface Area $\left(\mathrm{m}^{2} / \mathrm{g}\right)$} & \multirow{2}{*}{ Pore Size (nm) } \\
\hline & & & XRD & TEM & & \\
\hline $\mathrm{Ni} / \mathrm{Al}_{2} \mathrm{O}_{4}$ & 750 & 0.29 & 15.0 & - & 46 & 7.0 \\
\hline $\mathrm{Ni} / \mathrm{Al}_{2} \mathrm{O}_{3}(\mathrm{~A})$ & 750 & 0.32 & 4.4 & 6.8 & 111 & 11.8 \\
\hline $\mathrm{Ni} / \mathrm{Al}_{2} \mathrm{O}_{3}(\mathrm{~B})$ & 850 & 0.32 & 5.5 & 7.7 & 106 & 12.1 \\
\hline $\mathrm{Ni} / \mathrm{Al}_{2} \mathrm{O}_{3}(\mathrm{C})$ & 950 & 0.29 & 6.6 & 8.1 & 87 & 13.2 \\
\hline $\mathrm{K}-\mathrm{Ni} / \mathrm{Al}_{2} \mathrm{O}_{3}$ & 950 & 0.30 & 19.2 & 24.5 & 88 & 13.3 \\
\hline $\mathrm{Ca}-\mathrm{Ni} / \mathrm{Al}_{2} \mathrm{O}_{3}$ & 950 & 0.30 & 18.3 & 24.7 & 86 & 13.8 \\
\hline $\mathrm{Sr}-\mathrm{Ni} / \mathrm{Al}_{2} \mathrm{O}_{3}$ & 950 & 0.30 & 19.1 & 24.6 & 90 & 13.2 \\
\hline
\end{tabular}

Table 5. The results of catalytic performance test for the SR of glycerol over the prepared Ni-based catalysts. A, B, and C stand for calcination temperatures of 750, 850 , and $950{ }^{\circ} \mathrm{C}$, respectively [83] (used with copyright permission).

\begin{tabular}{|c|c|c|c|c|c|c|}
\hline \multirow{2}{*}{ Catalyst } & \multirow{2}{*}{ Reaction Temp. $\left({ }^{\circ} \mathrm{C}\right)$} & \multirow{2}{*}{ Reaction Time (h) } & \multirow{2}{*}{ Glycerol Conversion (\%) } & \multicolumn{2}{|c|}{ Selectivity (\%) } & \multirow{2}{*}{ Coke Formation ( $\mathrm{g} / \mathrm{g}$ cat $\cdot \mathrm{h})$} \\
\hline & & & & $\mathrm{H}_{2}$ & $\mathrm{CH}_{4}$ & \\
\hline $\mathrm{NiAl}_{2} \mathrm{O}_{4}$ & 800 & 24 & 75 & 60 & 8.2 & 0.521 \\
\hline $\mathrm{Ni} / \mathrm{Al}_{2} \mathrm{O}_{3}(\mathrm{~A})$ & 800 & 24 & 94 & 65 & 6.2 & 0.157 \\
\hline $\mathrm{Ni} / \mathrm{Al}_{2} \mathrm{O}_{3}(\mathrm{~B})$ & 800 & 24 & 94 & 64 & 5.9 & 0.149 \\
\hline $\mathrm{Ni} / \mathrm{Al}_{2} \mathrm{O}_{3}(\mathrm{C})$ & 800 & 24 & 95 & 65 & 5.7 & 0.104 \\
\hline $\mathrm{Ni} / \mathrm{Al}_{2} \mathrm{O}_{3}(\mathrm{~A})$ & 600 & 24 & 86 & 64 & 4.1 & 0.356 \\
\hline $\mathrm{Ni} / \mathrm{Al}_{2} \mathrm{O}_{3}(\mathrm{~B})$ & 600 & 24 & 88 & 64 & 4.1 & 0.284 \\
\hline $\mathrm{Ni} / \mathrm{Al}_{2} \mathrm{O}_{3}(\mathrm{C})$ & 600 & 24 & 90 & 64 & 2.1 & 0.188 \\
\hline $\mathrm{K}-\mathrm{Ni} / \mathrm{Al}_{2} \mathrm{O}_{3}$ & 800 & 100 & 93 & 60 & 4.6 & 0.008 \\
\hline $\mathrm{Ca}-\mathrm{Ni} / \mathrm{Al}_{2} \mathrm{O}_{3}$ & 800 & 100 & 94 & 60 & 4.1 & 0.043 \\
\hline $\mathrm{Sr}-\mathrm{Ni} / \mathrm{Al}_{2} \mathrm{O}_{3}$ & 800 & 100 & 94 & 65 & 0.4 & 0.001 \\
\hline $\mathrm{K}-\mathrm{Ni} / \mathrm{Al}_{2} \mathrm{O}_{3}$ & 600 & 24 & 84 & 63 & 4.2 & 0.217 \\
\hline $\mathrm{Ca}-\mathrm{Ni} / \mathrm{Al}_{2} \mathrm{O}_{3}$ & 600 & 24 & 85 & 63 & 3.9 & 0.148 \\
\hline $\mathrm{Sr}-\mathrm{Ni} / \mathrm{Al}_{2} \mathrm{O}_{3}$ & 600 & 24 & 87 & 63 & 3.7 & 0.136 \\
\hline
\end{tabular}


Figure 8 shows the resulsust of thermogravimetric analysis (TGA) for the used catalysts in the SR of glycerol, it was concluded that high calcination temperatures could improve the coke resistance and led to more durable catalysts. Among synthesized catalysts, the $\mathrm{Sr}-\mathrm{Ni} / \gamma-\mathrm{Al}_{2} \mathrm{O}_{3}$ catalyst showed the best stability over coke deposition in the SR of glycerol [83]. Based on the research conducted by Oemar et al. [80] it has also been confirmed that the addition of Sr could drastically improve the surface catalytic activity in the SR of toluene. Bobadilla et al. [79] reported that Ni-based catalysts doped with Sn can increase the stability of the catalyst and decrease the coke formation. In another research, Kitamura et al. [84], investigated the $\mathrm{SR}$ of glycerin $\mathrm{Ni} / \mathrm{ZrO}_{2}$ catalysts. The addition of $\mathrm{CaO}$ to the support $\mathrm{ZrO}_{2}$ enhanced the catalytic performance. In this regard, the synthesized $\mathrm{NiO} / \mathrm{CaO}-\mathrm{ZrO}_{2}$ catalyst exhibited glycerin conversion and hydrogen yield of 89 and $74 \%$ at $600{ }^{\circ} \mathrm{C}$, respectively. In addition, the coke deposition was also reduced from 4.2 to $2 \%$.

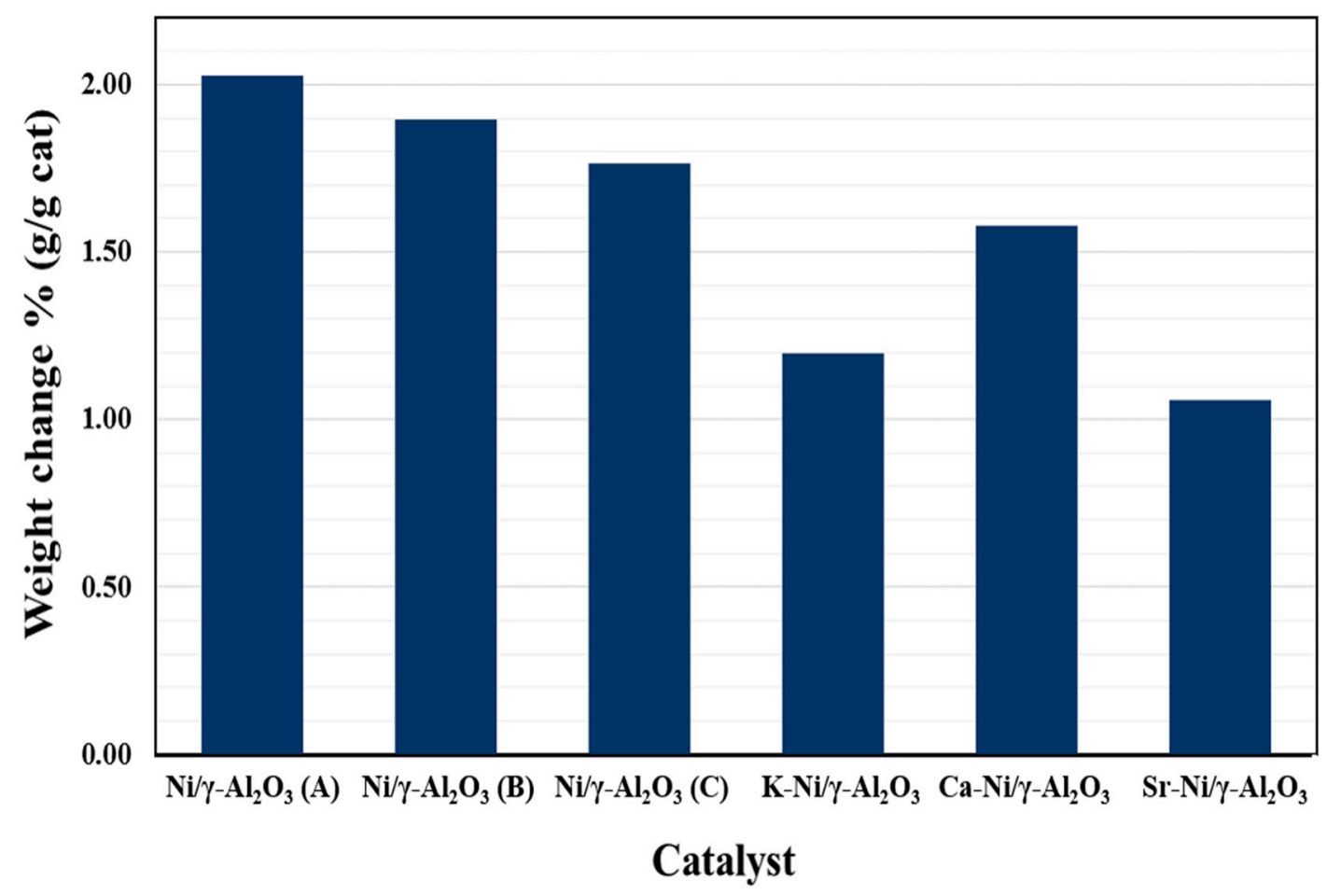

Figure 8. The TGA analysis for used catalysts in the SR of glycerol [83] (redrawn with copyright permission).

In another research work, Moon et al. [85] studied the addition of $\mathrm{Fe}, \mathrm{Ce}, \mathrm{La}$, and $\mathrm{Cr}$ to Ni-based catalysts for the SR of glycerol in various reaction conditions $\left(350 \sim 650^{\circ} \mathrm{C}\right.$ and $\left.1 \sim 8 \mathrm{bar}\right)$. The contents of $\mathrm{Ni}, \mathrm{Fe}$, and $\mathrm{X}$ were maintained at 15,3 , and $1 \%$ respectively, whereas $\mathrm{X}$ stands for $\mathrm{Ce}, \mathrm{La}$, and $\mathrm{Cr}$. Table 6 summarized the physicochemical properties of synthesized catalysts. The $\mathrm{Ni}-\mathrm{Fe}-\mathrm{Ce} / \mathrm{Al}_{2} \mathrm{O}_{3}$ catalyst showed a higher surface area and $\mathrm{Ni}$ dispersion.

Table 6. Physicochemical properties of the prepared Ni-based Fe promoted catalysts [85] (used with copyright permission).

\begin{tabular}{|c|c|c|c|c|c|c|c|}
\hline \multirow{2}{*}{ Catalyst } & \multicolumn{5}{|c|}{ Composition (wt\%) } & \multirow{2}{*}{ BET Surface Area $\left(\mathrm{m}^{2} / \mathrm{g}\right) *$} & \multirow{2}{*}{ Metal Dispersion (\%) ** } \\
\hline & $\mathrm{Ni}$ & $\mathrm{Fe}$ & $\mathrm{Ce}$ & La & $\mathrm{Cr}$ & & \\
\hline $\mathrm{Ni}-\mathrm{Fe}-\mathrm{Ce} / \mathrm{Al}_{2} \mathrm{O}_{3}$ & 15 & 3 & 1 & - & - & 136 & 0.22 \\
\hline $\mathrm{Ni}-\mathrm{Fe}-\mathrm{La} / \mathrm{Al}_{2} \mathrm{O}_{3}$ & 15 & 3 & - & 1 & - & 129 & 0.17 \\
\hline $\mathrm{Ni}-\mathrm{Fe}-\mathrm{Cr} / \mathrm{Al}_{2} \mathrm{O}_{3}$ & 15 & 3 & - & - & 1 & 125 & 0.08 \\
\hline
\end{tabular}

${ }^{*}$ Estimated from $\mathrm{N}_{2}$ adsorption; ** estimated from $\mathrm{H}_{2}$ chemisorption. 
Figure 9a shows the TGA profiles of the deposited coke on the catalysts after the SR of glycerol. It was found that the first weight loss at a temperature range of $50 \sim 200^{\circ} \mathrm{C}$ was related to physisorbed $\mathrm{H}_{2} \mathrm{O}$ and the second weight loss at $400 \sim 500{ }^{\circ} \mathrm{C}$ was caused by carbonaceous components adsorbed on the surface of the catalyst. The ceria promoted Ni-Fe-Ce/ $\mathrm{Al}_{2} \mathrm{O}_{3}$ catalyst showed lower carbonaceous deposition than the other catalysts. Go et al. [75] proposed that $\mathrm{CeO}_{2}$ is capable of storing oxygen molecules at the catalyst surface, which hinders the coke formation.
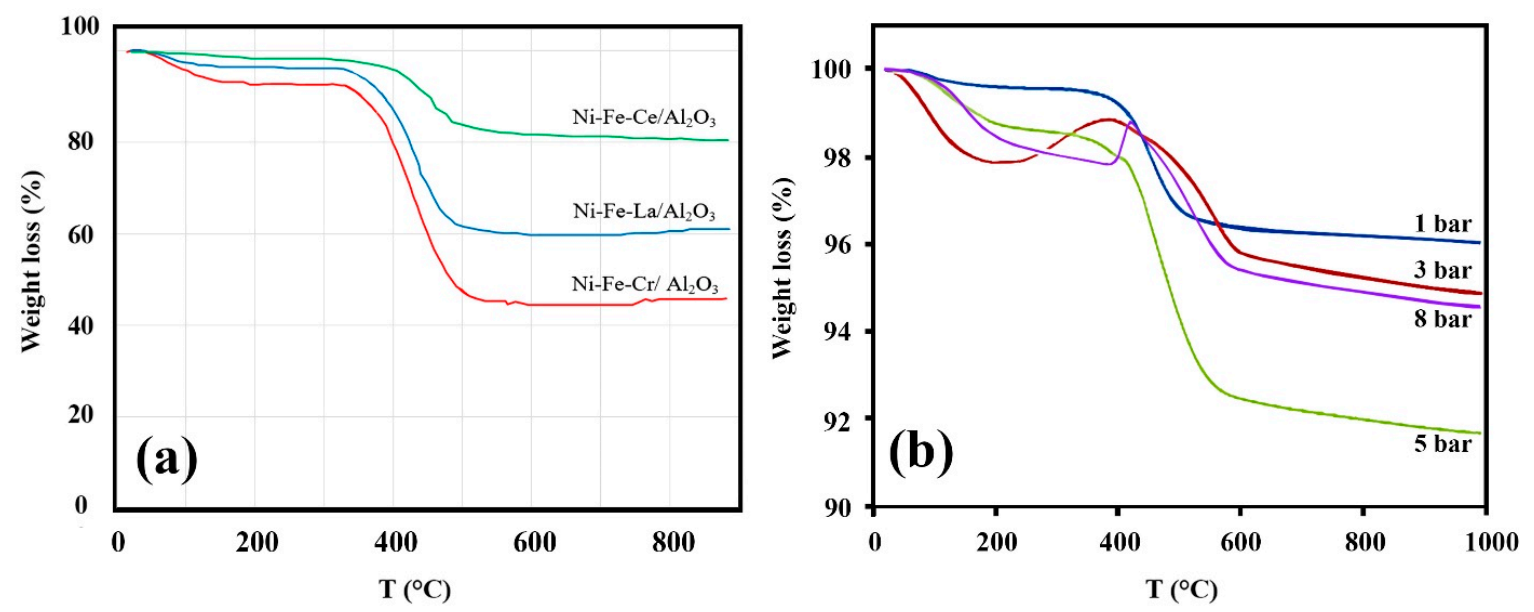

Figure 9. (a) TGA graph for (a) synthesized Ni-based catalysts at $450{ }^{\circ} \mathrm{C}$ and 1 bar, (b) used Ni-Fe-Ce/ $/ \mathrm{Al}_{2} \mathrm{O}_{3}$ catalyst at $450{ }^{\circ} \mathrm{C}$, and various pressures in the SR of glycerol [85] (redrawn with copyright permission).

Table 7 presents the summary of glycerol conversion and hydrogen selectivity results in the SR of glycerol using promoted Ni-based catalysts. The Ni-Fe-Ce/ $\mathrm{Al}_{2} \mathrm{O}_{3}$ catalyst has also exhibited significant catalytic performance with glycerol conversion and $\mathrm{H}_{2}$ selectivity of 94.1 and $64.0 \%$, respectively.

Table 7. The catalytic performance in the SR of glycerol over Ni-based Fe modified catalysts [85] (used with copyright permission).

\begin{tabular}{cccccc}
\hline \multirow{2}{*}{\begin{tabular}{c} 
Catalyst \\
\cline { 3 - 6 }
\end{tabular}} & \multirow{2}{*}{ Glycerol Conversion (\%) } & \multirow{2}{*}{$\mathbf{H}_{\mathbf{2}}$ Selectivity (\%) } & \multicolumn{3}{c}{ C1 Selectivity (\%) } \\
\cline { 4 - 6 } & & & $\mathbf{C O}$ & $\mathbf{C H}_{\mathbf{4}}$ & $\mathbf{C O}_{\mathbf{2}}$ \\
\hline $\mathrm{Ni}-\mathrm{Fe}-\mathrm{Ce} / \mathrm{Al}_{2} \mathrm{O}_{3}$ & 94.1 & 64.0 & 1.3 & 2.7 & 32.0 \\
$\mathrm{Ni}-\mathrm{Fe}-\mathrm{La} / \mathrm{Al}_{2} \mathrm{O}_{3}$ & 82.8 & 63.5 & 2.4 & 2.5 & 31.6 \\
$\mathrm{Ni}-\mathrm{Fe}-\mathrm{Cr} / \mathrm{Al}_{2} \mathrm{O}_{3}$ & 59.0 & 63.3 & 4.5 & 1.5 & 30.7 \\
\hline
\end{tabular}

Reaction condition: $450{ }^{\circ} \mathrm{C}$ and GHSV $=7300 \mathrm{~mL} / \mathrm{g}$-cat $\cdot \mathrm{h}$.

It was found that the introduction of Ce avoids the formation of unsaturated hydrocarbons via the secondary dehydration reactions and consequently decreases the coke deposition.

Figure $9 \mathrm{~b}$ illustrates TGA results for the synthesized catalysts in the SR of glycerol at $450{ }^{\circ} \mathrm{C}$ and various pressures (1 8 bar). It was observed that the coke deposition had been increased when the pressure in the SR of glycerol was increased, which reveals the positive impact of atmospheric pressure for avoiding coke formation.

As already discussed, the $\mathrm{Ca}$ and $\mathrm{Mg}$ had increased the catalytic performance of the Ni-based catalysts through reducing the Ni particle size with a better dispersion and stronger interaction on the support. Huang et al. [86] studied the addition of transition metals ( $\mathrm{La}, \mathrm{Ce}, \mathrm{Y}, \mathrm{Zr}$, or Mo) as the second promoter to the modified $\mathrm{Ni} / \mathrm{Al}_{2} \mathrm{O}_{3}$ catalyst with $\mathrm{Ca}$ and $\mathrm{Mg}$ (nominated as $\mathrm{CMA}$ ). This approach assists in decreasing the acidic sites in order to increase the catalytic stability in the SR of glycerol. Table 8 summarized the reaction results for SR of glycerol over synthesized catalysts. It was found that the NiMoLa/CMA significantly increased the catalytic performance, including glycerol conversion (99\%), hydrogen selectivity (63.2\%), and catalyst stability in $42 \mathrm{~h}$. 
Table 8. Catalytic properties of different catalysts in SR of glycerol * [86] (used with copyright permission).

\begin{tabular}{|c|c|c|c|c|c|c|c|c|}
\hline \multirow{2}{*}{ Catalysts } & \multirow{2}{*}{$\begin{array}{c}\text { Glycerol } \\
\text { Conversion (mol\%) }\end{array}$} & \multirow{2}{*}{$\begin{array}{l}\text { Conversion to } \\
\text { Gaseous Products }\end{array}$} & \multirow{2}{*}{$\begin{array}{l}\text { Gas Vol. Produced } \\
\text { in } 2 \mathrm{~h} \mathrm{(L)}\end{array}$} & \multirow{2}{*}{$\begin{array}{l}\text { Production Ratio } \\
\text { (L/gG) } * *\end{array}$} & \multicolumn{4}{|c|}{ Gas Product Distribution (mol\%) } \\
\hline & & & & & $\mathrm{H}_{2}$ & $\mathrm{CO}$ & $\mathrm{CO}_{2}$ & $\mathrm{CH}_{4}$ \\
\hline $\mathrm{Ni} / \gamma \mathrm{Al}_{2} \mathrm{O}_{3}$ & 63.9 & 54.1 & 34.4 & 1.17 & 74.1 & 6.4 & 17.9 & 1.6 \\
\hline $\mathrm{NiMg} / \gamma \mathrm{Al}_{2} \mathrm{O}_{3}$ & 83.7 & 58.1 & 36.9 & 1.26 & 74.8 & 6.4 & 16.6 & 2.2 \\
\hline $\mathrm{Ni} / \mathrm{CMA}^{* * *}$ & 84.6 & 68.4 & 43.5 & 1.48 & 67.9 & 9.2 & 20.6 & 2.3 \\
\hline NiLa/CMA & 84.0 & 66.2 & 42.1 & 1.43 & 71.8 & 8.1 & 17.3 & 2.7 \\
\hline $\mathrm{NiZr/CMA}$ & 63.1 & 38.1 & 24.2 & 0.82 & 68.2 & 9.4 & 19.2 & 3.2 \\
\hline NiMo/CMA & 93.4 & 93.0 & 57.3 & 1.95 & 65.2 & 10.5 & 19.9 & 4.4 \\
\hline NiMoLa/CMA & 99.1 & 99.0 & 60.0 & 1.98 & 63.2 & 17.7 & 14.1 & 4.9 \\
\hline
\end{tabular}

\section{SR of Glycerol over the Perovskite-Based Catalyst}

Perovskite is defined in the form of $\mathrm{ABO}_{3}$, where $\mathrm{A}$ and $\mathrm{B}$ present the rare-earth cation and transition metal, respectively. The corners of the unit cell are generally concurred by the A sites while B sites are placed in the center with a coordination number of 12 and 6, respectively [87]. Perovskite type oxides have received significant attention because of their unique crystal structures in chemical processes such as steam reforming of various hydrocarbons such as methane, ethanol, and glycerol [88-91]. Metallic particles with high dispersion could be achieved through the reduction when using perovskite as the support. This feature known as high oxygen mobility can drastically decrease the coke deposition on the catalyst surface in steam reforming reactions.

Furthermore, in terms of hydrogen production, the catalytic performance was improved when using perovskite supported catalysts. In this regard, Kamonsuangkasem et al. [29] found that in the reduced $\mathrm{CeAlO}_{3}$ perovskite, the interaction of $\mathrm{Ni}$ and alumina was decreased which consequently influenced the amount of Brønsted acid sites. Therefore, dehydration of condensable intermediates was fascinated, and more hydrogen was produced. In this regard, Franchini et al. [92] studied the SR of glycerol using $\mathrm{La}_{1-x} \mathrm{Ce}_{x} \mathrm{NiO}_{3}$ catalysts, and they also confirmed that the mentioned behavior could be attributed to the presence of both $\mathrm{Ce}$ and perovskite. Through their work, it was found that to prepare a catalyst which includes $\mathrm{CeO}_{2}-\mathrm{La}_{2} \mathrm{O}_{3}$ with improved coke resistance, considering higher contents of Ce could be obliging. In another research, Xie et al. [93] studied the SR of glycerol using $\mathrm{La}_{0.7} \mathrm{Ce}_{0.3} \mathrm{NiO}_{3}$ perovskite-type mixed oxides synthesized by the co-precipitation method in various calcination temperatures and concentrations. The prepared samples were nominated as LT-X-Y whereas $\mathrm{T}$ stands for the calcination temperature $(700,900), X$ shows the molar concentration of nitrate solution (0.03 3), and $\mathrm{Y}$ is the molar concentration of the precipitant (0.1 1.9). Figure 10 illustrates the glycerol conversion and yield for the gaseous products in the SR of the glycerol over synthesized catalysts in this work. It was found that the L700-0.3-0.6 catalyst showed lower coke deposition and catalytic stability with proper activity. Furthermore, for all synthesized $\mathrm{La}_{0.7} \mathrm{Ce}_{0.3} \mathrm{NiO}_{3}$ perovskite-type mixed oxide catalysts the low yield of $\mathrm{CH}_{4}$ represents that the hydrogenation between produced hydrogen and the $\mathrm{CO}$ or $\mathrm{CO}_{2}$ was almost omitted.

Moon et al. [94] studied the SR of glycerol for the production of hydrogen at low temperatures using $\mathrm{Cu}$ decorated perovskite catalysts through the vapor phase reaction conditions. Table 9 shows the catalytic performance for SR of glycerol. 


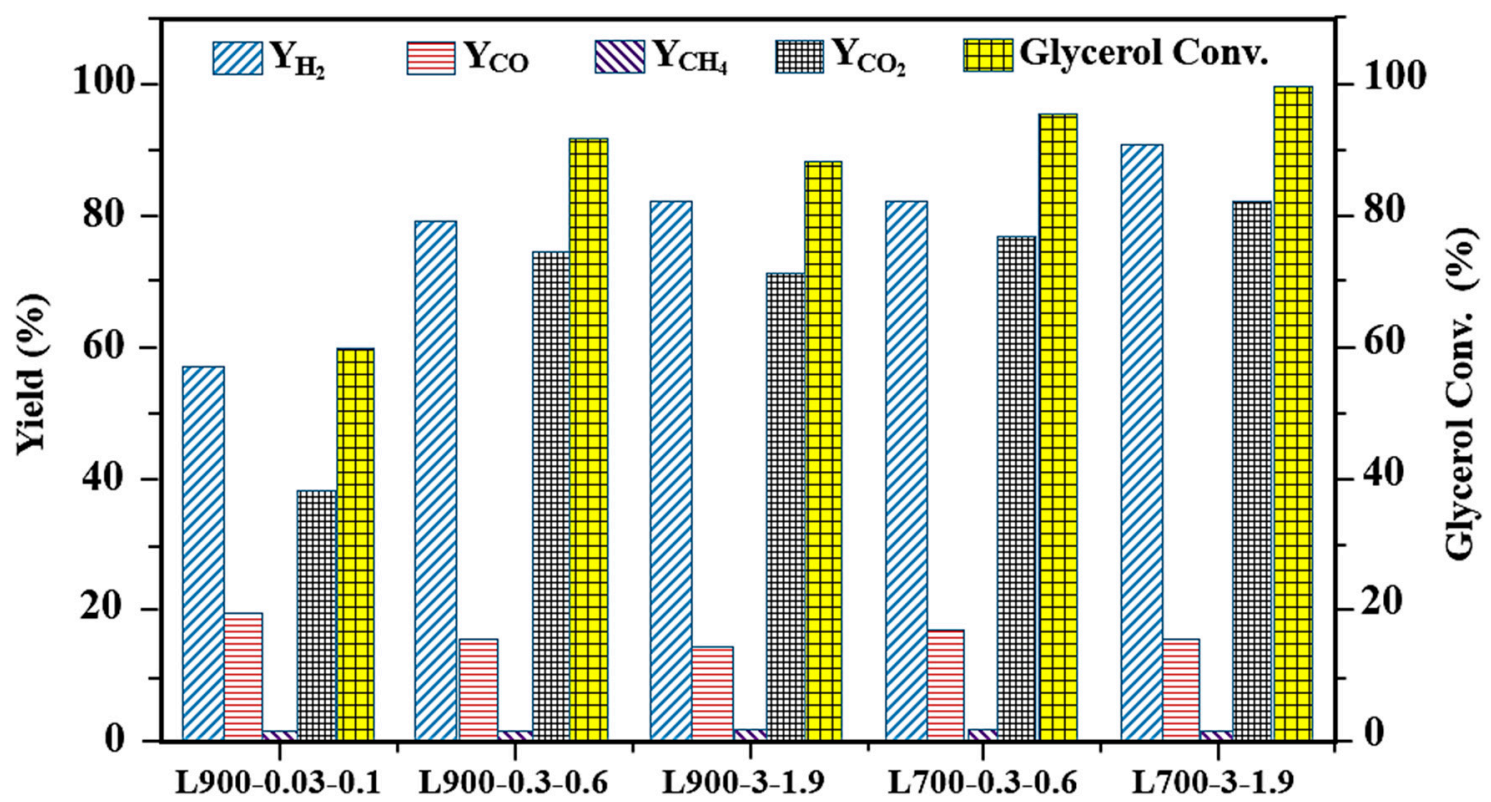

Figure 10. The glycerol conversion and yield for the gaseous products in SR of the glycerol over LT-X-Y perovskite-type mixed oxides $\left(575^{\circ} \mathrm{C}, \mathrm{H}_{2} \mathrm{O} / \mathrm{C}_{3} \mathrm{H}_{8} \mathrm{O}_{3}\right.$ molar ratio of 15 , and $49.7 \mathrm{~g} \mathrm{~h} / \mathrm{mol}$ ) [93] (redrawn with copyright permission).

Table 9. Catalytic performance for SR of glycerol [94] (used with copyright permission).

\begin{tabular}{ccccccc}
\hline \multirow{2}{*}{$\mathbf{T}\left({ }^{\circ} \mathbf{C}\right)$} & \multirow{2}{*}{ Catalyst } & Glycerol Conversion (\%) & \multicolumn{4}{c}{ Selectivity (\%) } \\
\cline { 4 - 7 } & & & $\mathbf{H}_{\mathbf{2}}$ & $\mathbf{C O}$ & $\mathbf{C H}_{\mathbf{4}}$ & $\mathbf{C O}_{\mathbf{2}}$ \\
\hline \multirow{3}{*}{550} & $\mathrm{LaNiO}_{3}$ & 35 & 69 & 0.3 & 1.3 & 30 \\
& $\mathrm{LaNi}_{0.9} \mathrm{Cu}_{0.1} \mathrm{O}_{3}$ & 38 & 68 & 2.7 & 1.0 & 28 \\
& $\mathrm{LaNi}_{0.5} \mathrm{Cu}_{0.5} \mathrm{O}_{3}$ & 58 & 68 & 1.1 & 0.6 & 30 \\
& $\mathrm{LaNiO}_{3}$ & 73 & 66 & 2.7 & 3.5 & 28 \\
& $\mathrm{LaNi}_{0.9} \mathrm{Cu}_{0.1} \mathrm{O}_{3}$ & 57 & 67 & 2.6 & 2.6 & 27 \\
& $\mathrm{LaNi}_{0.5} \mathrm{Cu}_{0.5} \mathrm{O}_{3}$ & 67 & 2.8 & 2.8 & 27 \\
\hline
\end{tabular}

Reaction conditions: $\mathrm{H}_{2} \mathrm{O} / \mathrm{C}_{3} \mathrm{H}_{8} \mathrm{O}_{3}$ (molar ratio) $=9$, LHSV: $10,000 \mathrm{~h}^{-1}$, and atmospheric pressure.

The $\left(\mathrm{LaNi}_{0.9} \mathrm{Cu}_{0.1} \mathrm{O}_{3}\right)$ catalysts were synthesized by a perovskite precursor, exhibiting high catalytic performance in SR of glycerol at $650{ }^{\circ} \mathrm{C}$, which could be a result of uniform dispersion of $\mathrm{Cu}$ particles. Moreover, the addition of $\mathrm{Cu}$ assisted in operating the reaction at a lower temperature as the resistance towards the coke deposition was improved. This approach also led to a significant decrease in the $\mathrm{Ni}$ sintering and consequently retaining the catalytic activity. It was understood that configuration of $\mathrm{Cu}-\mathrm{Ni}$ nanoparticles on the perovskite-type oxides had enhanced the glycerol decomposition and dehydration process as well [94].

Aman et al. [88] studied the synthesized $\mathrm{LaNiO}_{3}$ and $\mathrm{LaCoO}_{3}$ via reverse microemulsion in SR of glycerol for the production of hydrogen. They found that at a low temperature of $400{ }^{\circ} \mathrm{C}$ and $\mathrm{H}_{2} \mathrm{O} / \mathrm{C}_{3} \mathrm{H}_{8} \mathrm{O}_{3}$ molar ratio of 15 , the synthesized $\mathrm{LaNiO}_{3}$ has approximately three times more catalytic activity compared to the $\mathrm{LaCoO}_{3}$ catalyst. It is important to notice that the SR of glycerol using Ni-based catalysts owns a lower activation energy compared to the Co-based catalysts. Therefore, it is expected that Ni-based catalysts would have better catalytic performance in terms of glycerol conversion and hydrogen selectivity at low temperature while the Co-based catalyst is less capable for the coke deposition at higher temperatures. Moreover, the methane yield could be considered as a parameter for evaluating how $\mathrm{C}-\mathrm{C}$ bond cleavages occur over the synthesized catalysts. For instance, in the case of Ni-based catalysts $\left(\mathrm{Ni}\right.$ ex $\left.\mathrm{LaNiO}_{3}\right)$, more methane was produced compared to the Co ex $\mathrm{LaNiO}_{3}$ which resembles that the rate of $\mathrm{C}-\mathrm{C}$ bond cleavage is higher. Ramesh et al. [95] investigated the $\mathrm{SR}$ of the glycerol over synthesized $\mathrm{LaNiO}_{3}$ with and without templates. The core idea was to study 
the effect of various particle sizes of $\mathrm{NiO}$ in SR of glycerol (Table 10). It was found that even though the $\mathrm{LaNiO}_{3}$ synthesized with the template showed a lower BET surface area, but a better catalytic performance compared to $\mathrm{NiAl}_{2} \mathrm{O}_{3}$ was obtained over this catalyst at 550 and $650{ }^{\circ} \mathrm{C}$.

Table 10. Catalytic performance of different catalysts in SR of glycerol [95] (used with copyright permission).

\begin{tabular}{|c|c|c|c|c|c|c|c|}
\hline \multirow{2}{*}{$\mathrm{T}\left({ }^{\circ} \mathrm{C}\right)$} & \multirow{2}{*}{ Catalyst } & \multirow{2}{*}{ BET Surface Area $\left(\mathrm{m}^{2} / \mathrm{g}\right)$} & \multirow{2}{*}{ Glycerol Conversion (\%) } & \multicolumn{4}{|c|}{ Selectivity (\%) } \\
\hline & & & & $\mathrm{H}_{2}$ & $\mathrm{CO}$ & $\mathrm{CH}_{4}$ & $\mathrm{CO}_{2}$ \\
\hline \multirow{3}{*}{550} & $\mathrm{LaNiO}_{3}$ * & 10.7 & 48 & 70 & 0.3 & 0.8 & 28 \\
\hline & $\mathrm{LaNiO}_{3}$ & 15.0 & 41 & 69 & 2.7 & 1.3 & 30 \\
\hline & $\mathrm{NiAl}_{2} \mathrm{O}_{3}$ & 110 & 5 & 67 & 1.1 & 1.4 & 20 \\
\hline \multirow{3}{*}{650} & $\mathrm{LaNiO}_{3}$ * & 10.7 & 72 & 70 & 2.7 & 2.4 & 24 \\
\hline & $\mathrm{LaNiO}_{3}$ & 15.0 & 68 & 66 & 2.6 & 3.5 & 28 \\
\hline & $\mathrm{NiAl}_{2} \mathrm{O}_{3}$ & 110 & 56 & 68 & 2.8 & 2.8 & 25 \\
\hline
\end{tabular}

Wu et al. [96] studied the $\mathrm{SR}$ of glycerol over the $\mathrm{La}_{1-x} \mathrm{Ca}_{x} \mathrm{NiO}_{3}$ perovskite-type oxides. They found that the partial substitution of lanthanum with calcium could drastically influence the physicochemical properties of the catalyst. In fact, the perovskite-type oxides are capable of providing the uniform distribution of the nickel, lanthanum, and/or calcium. Furthermore, after the characterization of the used catalysts, it was found that the coke formation over active sites could be the major reason for the catalyst deactivation. Narrow nickel particles that have a stronger interaction with the support can show higher catalytic stability during the SR of glycerol.

\section{The SR of Glycerol over Hydrotalcite-Based Catalyst}

Hydrotalcites are double-layered hydroxides known as the layered synthetic minerals anionic clays. These brucite-like layers have the general formula of $\left[\mathrm{M}^{\mathrm{II}}{ }_{1-\mathrm{x}} \mathrm{M}^{\mathrm{III}}{ }_{\mathrm{x}}(\mathrm{OH})_{2}\right]^{\mathrm{x}+}\left[\mathrm{A}^{\mathrm{n}-}{ }_{\mathrm{x} / n} \cdot \mathrm{yH}_{2} \mathrm{O}\right]^{\mathrm{x}-}$, whereas the $\mathrm{M}(\mathrm{II})$ and $\mathrm{M}(\mathrm{III})$ stand for the divalent and trivalent cations. The $\mathrm{n}$-valent anion number of interlayer molecules of $\mathrm{H}_{2} \mathrm{O}$ was shown by $\mathrm{A}^{\mathrm{n}-}$ and $\mathrm{y}$, respectively. Calcination of these types of double-layered hydroxides ends with a uniform dispersion of MII and MIII oxides. In this regard, it was believed that the $\mathrm{Ni}-\mathrm{Mg}-\mathrm{Al}$ mixed oxides derivate from hydrotalcite had presented a proper catalytic performance in various catalytic processes such as dry and steam reforming of methane [97-100] and ethanol [101-104]. Furthermore, the $\mathrm{Cu}-\mathrm{Mg}-\mathrm{Al}$ hydrotalcite type catalysts also showed superior catalytic activity in the water-gas shift (WGS) reaction [105]. The bimetallic of $\mathrm{Ni}$ and $\mathrm{Cu}$ catalyst has been initially studied for the SR of ethanol with decreased coke deposition [106-108], however even though it was expected that this configuration could be efficiently applied for the SR of glycerol, but Manfro et al. [109] investigated the Ni-Cu hydrotalcite based catalysts with $20 \mathrm{wt} \%$ of nickel oxide and 0,5 , and $10 \mathrm{wt} \%$ of copper oxide. It was recognized that the addition of the copper had a negative impact on the conversion of glycerol, and the maximum conversion was obtained for the bare Ni-based catalyst. Furthermore, the results demonstrated that the Ni10Cu exhibited higher glycerol conversion in comparison to the $\mathrm{Ni5} \mathrm{Cu}$ catalyst.

Dahdah et al. [110] investigated the SR of glycerol over Ru-Mg-Al hydrotalcite-derived mixed oxides synthesized through co-precipitation (COP) and impregnation (IMP). The reaction conditions for the SR of glycerol were as following: $400 \sim 700{ }^{\circ} \mathrm{C}, \mathrm{H}_{2} \mathrm{O} / \mathrm{C}_{3} \mathrm{H}_{8} \mathrm{O}_{3}$ (molar ratio) $=9$, and the stability test was carried out at $600{ }^{\circ} \mathrm{C}$. The Ru-Mg-Al (IMP) exhibited sufficiently better catalytic performance, which could be due to the ensemble effect and the facilitated accessibility to the active sites. In another research work, Simone et al. [111] suggested that Pt-based catalysts supported on hydrotalcite consist of $\mathrm{Mg}$ and $\mathrm{Al}$ in the SR of glycerol. It was reported that the hydrotalcite catalyst with $\mathrm{Mg} / \mathrm{Al}=3$ showed higher catalytic activity than the hydrotalcite catalyst with $\mathrm{Mg} / \mathrm{Al}=5$. In this regard, Moon et al. [112] studied nanosized Ni-based hydrotalcite-like catalysts for application in the SR of glycerol. The Ni/ $\mathrm{Al}_{2} \mathrm{O}_{3}$ catalyst was synthesized by the impregnation method as a reference for the comparative analysis, and the $\mathrm{Ni}-\mathrm{MgAl}$ (Ni-based hydrotalcite) catalyst was synthesized through 
the solid phase crystallization method. The reaction condition in a fixed bed reactor was as follows: $700 \sim 800{ }^{\circ} \mathrm{C}, 1$ bar, $\mathrm{H}_{2} \mathrm{O} / \mathrm{C}_{3} \mathrm{H}_{8} \mathrm{O}_{3}$ (molar ratio) = 9, $10 \mathrm{wt} \%$ of glycerol, GHSV = 10,000 $\mathrm{h}^{-1}$.

It was found that the particle size of $\mathrm{Ni}$ in the $\mathrm{Ni} / \mathrm{MgAl}$ catalyst is smaller than that in the $\mathrm{Ni} / \mathrm{Al}_{2} \mathrm{O}_{3}$ catalyst. The catalyst deactivation in the SR of glycerol was a consequence of sintered Ni particles and filamentous carbon deposited on the surface of the catalyst. A negligible amount of coke was formed on the surface of the $\mathrm{Ni} / \mathrm{MgAl}$ catalyst, with a coke formation rate per weight of the catalyst as $1.7 \times 10^{-2} \mathrm{~g}$ carbon/(h. gcat) which is much smaller than that over the $\mathrm{Ni} / \mathrm{Al}_{2} \mathrm{O}_{3}$ catalyst, $4.18 \times 10^{-2} \mathrm{~g}$ carbon/(h. gcat).

\section{Conclusions}

This paper reviewed and categorized the current state of knowledge on bio-hydrogen production through the SR of glycerol obtained from transesterification. Nickel-based catalysts are conventionally used for various SR of hydrocarbons, including glycerol. Carrying out the process at lower temperatures can lead to reducing the cost of energy for the commercialization of the process. It was found that the optimal temperature could be around $650{ }^{\circ} \mathrm{C}$, while the pressure is always maintained at atmospheric conditions. For enhancement of the efficiency in the SR of glycerol, various promoters were implicated, whereas $\mathrm{Ce}, \mathrm{Mg}$, and La were found to have a greater influence on lowering the coke deposition and sintering. Perovskite-type supports have exhibited stability as a result of the incorporation of other metal ions into the perovskite structure. In this regard, Ni-based catalysts supported on the $\mathrm{ZrO}_{2}$ and promoted with La showed high conversion at low temperatures. It was found that by adjusting the $\mathrm{Ni}$ content supported on the $\mathrm{SiO}_{2}-\mathrm{Al}_{2} \mathrm{O}_{3}$ catalyst, the catalytic performance can be sufficiently enhanced at low temperatures $\left(350 \sim 550^{\circ} \mathrm{C}\right)$. Using perovskite-type catalysts can lead to superior hydrogen selectivity and glycerol conversion. The $\mathrm{LaNi}_{0.9} \mathrm{Cu}_{0.1} \mathrm{O}_{3}$ catalysts synthesized by a perovskite precursor has shown high catalytic performance in SR of glycerol. It was suggested that nanosized Ni-based hydrotalcite-like catalysts for application in the SR of glycerol could be considered as potential candidates. The hydrotalcite catalysts can offer higher thermal stability and coke resistance. As for future work, it is suggested to simulate the feed composition for the development of the core technology for handling crude glycerol that contains various impurities based on the biomass source.

Funding: This work was supported and funded by the Korea Institute of Science and Technology (Project No. 2E30570) and Brain Pool Program through the National Research Foundation of Korea (NRF) which is funded by the Ministry of Science and ICT (2019H1D3A2A01102241).

Acknowledgments: The authors gratefully acknowledge all of their co-workers for their valuable research contributions that are summarized in the present review.

Conflicts of Interest: The authors declare no conflict of interest.

\section{References}

1. Chang, C.-J.; Lin, Y.-G.; Weng, H.-T.; Wei, Y.-H. Photocatalytic hydrogen production from glycerol solution at room temperature by ZnO-ZnS/graphene photocatalysts. Appl. Surf. Sci. 2018, 451, 198-206. [CrossRef]

2. Rúa, D.; Hernández, L. Phenomenological evaluation of industrial reformers for glycerol steam reforming. Int. J. Hydrogen Energy 2016, 41, 13811-13819. [CrossRef]

3. Song, J.H.; Han, S.J.; Song, I.K. Hydrogen Production by Steam Reforming of Ethanol Over Mesoporous $\mathrm{Ni}-\mathrm{Al}_{2} \mathrm{O}_{3}-\mathrm{ZrO}_{2}$ Catalysts. Catal. Surv. Asia 2017, 21, 114-129. [CrossRef]

4. Baykara, S.Z. Hydrogen: A brief overview on its sources, production and environmental impact. Int. J. Hydrogen Energy 2018, 43, 10605-10614. [CrossRef]

5. Seo, J.; Youn, M.; Song, I. Mesoporous Nickel-Alumina Catalysts for Hydrogen Production by Steam Reforming of Liquefied Natural Gas (LNG). Catal. Surv. Asia 2009, 14, 1-10. [CrossRef]

6. Sheikhbahaei, V.; Baniasadi, E.; Naterer, G. Experimental investigation of solar assisted hydrogen production from water and aluminum. Int. J. Hydrogen Energy 2018, 43, 9181-9191. [CrossRef] 
7. Arapova, M.V.; Pavlova, S.; Rogov, V.A.; Krieger, T.A.; Ishchenko, A.; Roger, A.-C. Ni(Co)-containing catalysts based on perovskite-like ferrites for steam reforming of ethanol. Catal. Sustain. Energy 2014, 2, 10-20. [CrossRef]

8. Almind, M.R.; Vendelbo, S.B.; Hansen, M.F.; Vinum, M.G.; Frandsen, C.; Mortensen, P.M.; Engbaek, J.S. Improving performance of induction-heated steam methane reforming. Catal. Today 2020, 342, 13-20. [CrossRef]

9. Choi, B.K.; Ok, H.J.; Moon, D.J.; Kim, J.H.; Park, N.C.; Kim, Y.C. Carbon deposition from the co2-steam reforming of methane over modified $\mathrm{Ni} / \gamma-\mathrm{Al}_{2} \mathrm{O}_{3}$ catalysts. J. Nanosci. Nanotechnol. 2015, 15, 391-395. [CrossRef]

10. Schwengber, C.A.; Alves, H.J.; Schaffner, R.A.; Da Silva, F.A.; Sequinel, R.; Bach, V.R.; Ferracin, R.J. Overview of glycerol reforming for hydrogen production. Renew. Sustain. Energy Rev. 2016, 58, 259-266. [CrossRef]

11. Yang, E.-H.; Noh, Y.S.; Hong, G.H.; Moon, D.J. Combined steam and $\mathrm{CO}_{2}$ reforming of methane over $\mathrm{La}_{1}-\mathrm{xSrxNiO} 3$ perovskite oxides. Catal. Today 2018, 299, 242-250. [CrossRef]

12. Tamošiūnas, A.; Valatkevičius, P.; Gimžauskaitè, D.; Valinčius, V.; Jeguirim, M. Glycerol steam reforming for hydrogen and synthesis gas production. Int. J. Hydrogen Energy 2017, 42, 12896-12904. [CrossRef]

13. Ghoreishi, S.; Moein, P. Biodiesel synthesis from waste vegetable oil via transesterification reaction in supercritical methanol. J. Supercrit. Fluids 2013, 76, 24-31. [CrossRef]

14. He, L.; Parra, J.M.S.; Blekkan, A.; Chen, D. Towards efficient hydrogen production from glycerol by sorption enhanced steam reforming. Energy Environ. Sci. 2010, 3, 1046-1056. [CrossRef]

15. Wang, C.; Dou, B.; Chen, H.; Song, Y.; Xu, Y.; Du, X.; Luo, T.; Tan, C. Hydrogen production from steam reforming of glycerol by Ni-Mg-Al based catalysts in a fixed-bed reactor. Chem. Eng. J. 2013, 220, 133-142. [CrossRef]

16. Pradima, J.; Kulkarni, M.R. Archna Review on enzymatic synthesis of value added products of glycerol, a by-product derived from biodiesel production. Res. Effic. Technol. 2017, 3, 394-405.

17. Yang, F.; Hanna, M.A.; Sun, R. Value-added uses for crude glycerol-a byproduct of biodiesel production. Biotechnol. Biofuels 2012, 5, 13. [CrossRef]

18. Valin, H.; Peters, D.; Berg, M.V.D.; Frank, S.; Havlik, P.; Forsell, N.; Hamelinck, C.; Pirker, J.; Mosnier, A.; Balkovic, J.; et al. The Land Use Change Impact of Biofuels Consumed in the Eu; ECOFYS: Utrecht, The Netherland, 2015.

19. Dou, B.; Zhang, H.; Song, Y.; Zhao, L.; Jiang, B.; He, M.; Ruan, C.; Chen, H.; Xu, Y. Hydrogen production from the thermochemical conversion of biomass: Issues and challenges. Sustain. Energy Fuels 2019, 3, 314-342. [CrossRef]

20. Kim, Y.C.; Moon, D.J. Sustainable Process for the Synthesis of Value-Added Products Using Glycerol as a Useful Raw Material. Catal. Surv. Asia 2019, 23, 10-22. [CrossRef]

21. Iriondo, A.; Barrio, V.; Cambra, J.F.; Arias, P.L.; Güemez, B.; Sanchez-Sanchez, M.; Navarro, R.; Fierro, J.L.G. Glycerol steam reforming over Ni catalysts supported on ceria and ceria-promoted alumina. Int. J. Hydrogen Energy 2010, 35, 11622-11633. [CrossRef]

22. Sad, M.; Duarte, H.A.; Vignatti, C.; Padró, C.; Apesteguia, C. Steam reforming of glycerol: Hydrogen production optimization. Int. J. Hydrogen Energy 2015, 40, 6097-6106. [CrossRef]

23. Wu, G.; Zhang, C.; Li, S.; Han, Z.; Wang, T.; Ma, X.; Gong, J. Hydrogen Production via Glycerol Steam Reforming over $\mathrm{Ni} / \mathrm{Al}_{2} \mathrm{O}_{3}$ : Influence of Nickel Precursors. ACS Sustain. Chem. Eng. 2013, 1, 1052-1062. [CrossRef]

24. Kousi, K.; Kondarides, D.; Verykios, X.; Papadopoulou, C. Glycerol steam reforming over modified $\mathrm{Ru} / \mathrm{Al}_{2} \mathrm{O}_{3}$ catalysts. Appl. Catal. A Gen. 2017, 542, 201-211. [CrossRef]

25. Senseni, A.Z.; Rezaei, M.; Meshkani, F. Glycerol steam reforming over noble metal nanocatalysts. Chem. Eng. Res. Des. 2017, 123, 360-366. [CrossRef]

26. Zamzuri, N.H.; Mat, R.; Amin, N.A.S.; Talebian-Kiakalaieh, A. Hydrogen production from catalytic steam reforming of glycerol over various supported nickel catalysts. Int. J. Hydrogen Energy 2017, 42, 9087-9098. [CrossRef]

27. Goula, M.; Charisiou, N.; Papageridis, K.; Siakavelas, G. Influence of the synthesis method parameters used to prepare nickel-based catalysts on the catalytic performance for the glycerol steam reforming reaction. Chin. J. Catal. 2016, 37, 1949-1965. [CrossRef] 
28. Veiga, S.; Bussi, J. Steam reforming of crude glycerol over nickel supported on activated carbon. Energy Convers. Manag. 2017, 141, 79-84. [CrossRef]

29. Kamonsuangkasem, K.; Therdthianwong, S.; Therdthianwong, A.; Thammajak, N. Remarkable activity and stability of $\mathrm{Ni}$ catalyst supported on $\mathrm{CeO}_{2}-\mathrm{Al}_{2} \mathrm{O}_{3}$ via $\mathrm{CeAlO}_{3}$ perovskite towards glycerol steam reforming for hydrogen production. Appl. Catal. B Environ. 2017, 218, 650-663. [CrossRef]

30. Dębek, R.; Motak, M.; Grzybek, T.; Gálvez, M.E.; Da Costa, P. A Short Review on the Catalytic Activity of Hydrotalcite-Derived Materials for Dry Reforming of Methane. Catalysts 2017, 7, 32. [CrossRef]

31. Shekoohi, K.; Hosseini, F.S.; Haghighi, A.H.; Sahrayian, A. Synthesis of some Mg/Co-Al type nano hydrotalcites and characterization. MethodsX 2017, 4, 86-94. [CrossRef]

32. Sikander, U.; Sufian, S.; Salam, M.A. A review of hydrotalcite based catalysts for hydrogen production systems. Int. J. Hydrogen Energy 2017, 42, 19851-19868. [CrossRef]

33. Silva, J.M.; Soria, M.A.; Madeira, L.M. Challenges and strategies for optimization of glycerol steam reforming process. Renew. Sust. Energ. Rev. 2015, 42, 1187-1213. [CrossRef]

34. Dang, C.; Yu, H.; Wang, H.; Peng, F.; Yang, Y. A bi-functional Co-CaO-Ca ${ }_{12} \mathrm{Al}_{14} \mathrm{O}_{33}$ catalyst for sorption-enhanced steam reforming of glycerol to high-purity hydrogen. Chem. Eng. J. 2016, 286, 329-338. [CrossRef]

35. Lima, D.S.; Calgaro, C.O.; Perez-Lopez, O.W. Hydrogen production by glycerol steam reforming over Ni based catalysts prepared by different methods. Biomass Bioenerg. 2019, 130, 105358. [CrossRef]

36. Zhang, B.; Tang, X.; Li, Y.; Xu, Y.; Shen, W. Hydrogen production from steam reforming of ethanol and glycerol over ceria-supported metal catalysts. Int. J. Hydrogen Energy 2007, 32, 2367-2373. [CrossRef]

37. Koc, S.; Avci, A.K. Reforming of glycerol to hydrogen over Ni-based catalysts in a microchannel reactor. Fuel Process. Technol. 2017, 156, 357-365. [CrossRef]

38. Shao, S.; Shi, A.-W.; Liu, C.-L.; Yang, R.-Z.; Dong, W.-S. Hydrogen production from steam reforming of glycerol over ni/cezro catalysts. Fuel Process. Technol. 2014, 125, 1-7. [CrossRef]

39. Ebshish, A.; Yaakob, Z.; Narayanan, B.; Bshish, A.; Daud, W.R.W. Steam reforming of glycerol over Ni supported alumina xerogel for hydrogen production. Energy Procedia. 2012, 18, 552-559. [CrossRef]

40. Sahraei, O.A.Z.; Luo, Y.; Abatzoglou, N.; Iliuta, M. Hydrogen production by glycerol steam reforming catalyzed by Ni-promoted Fe/Mg-bearing metallurgical wastes. Appl. Catal. B Environ. 2017, 219, 183-193. [CrossRef]

41. Nichele, V.; Signoretto, M.; Menegazzo, F.; Gallo, A.; Dal Santo, V.; Cruciani, G.; Cerrato, G. Glycerol steam reforming for hydrogen production: Design of Ni supported catalysts. Appl. Catal. B Environ. 2012, 111, $225-232$. [CrossRef]

42. Rossetti, I.; Gallo, A.; Dal Santo, V.; Bianchi, C.L.; Nichele, V.; Signoretto, M.; Finocchio, E.; Ramis, G.; Di Michele, A. Nickel Catalysts Supported Over $\mathrm{TiO}_{2}, \mathrm{SiO}_{2}$ and $\mathrm{ZrO}_{2}$ for the Steam Reforming of Glycerol. ChemCatChem 2012, 5, 294-306. [CrossRef]

43. Ming, F.; Qingli, X.; Wei, Q.; Zhikai, Z.; Suping, Z.; Yongjie, Y. Hydrogen production from glycerol steam reforming over $\mathrm{Ni} / \mathrm{La} / \mathrm{Co} / \mathrm{Al}_{2} \mathrm{O}_{3}$ catalyst. Energy Sources Part A Recover. Util. Environ. Eff. 2016, 38, 2128-2134. [CrossRef]

44. Kousi, K.; Chourdakis, N.; Matralis, H.; Kontarides, D.; Papadopoulou, C.; Verykios, X. Glycerol steam reforming over modified Ni-based catalysts. Appl. Catal. A Gen. 2016, 518, 129-141. [CrossRef]

45. Veiga, S.; Faccio, R.; Romero, M.; Bussi, J. Utilization of waste crude glycerol for hydrogen production via steam reforming over Ni-La-Zr catalysts. Biomass Bioenergy 2020, 135, 105508. [CrossRef]

46. Feng, P.; Huang, K.; Xu, Q.; Qi, W.; Xin, S.; Wei, T.; Liao, L.; Yan, Y. Ni supported on the CaO modified attapulgite as catalysts for hydrogen production from glycerol steam reforming. Int. J. Hydrogen Energy 2020, 45, 8223-8233. [CrossRef]

47. Veiga, S.; Romero, M.; Faccio, R.; Segobia, D.; Duarte, H.; Apesteguía, C.; Bussi, J. Hydrogen-rich gas production by steam and oxidative steam reforming of crude glycerol over Ni-La-Me mixed oxide catalysts (Me = Ce and/or Zr). Catal. Today 2020, 344, 190-198. [CrossRef]

48. Chen, D.; Wang, W.; Liu, C. Hydrogen production through glycerol steam reforming over beehive-biomimetic graphene-encapsulated nickel catalysts. Renew. Energy 2020, 145, 2647-2657. [CrossRef]

49. Suffredini, D.F.; Thyssen, V.V.; De Almeida, P.M.; Gomes, R.S.; Borges, M.C.; De Farias, A.M.D.; Assaf, E.M.; Fraga, M.A.; Brandão, S.T. Renewable hydrogen from glycerol reforming over nickel aluminate-based catalysts. Catal. Today 2017, 289, 96-104. [CrossRef] 
50. Bepari, S.; Pradhan, N.C.; Dalai, A.K. Selective production of hydrogen by steam reforming of glycerol over $\mathrm{Ni}$ /Fly ash catalyst. Catal. Today 2017, 291, 36-46. [CrossRef]

51. Charisiou, N.D.; Siakavelas, G.; Papageridis, K.N.; Baklavaridis, A.; Tzounis, L.; Polychronopoulou, K.; Goula, M.A. Hydrogen production via the glycerol steam reforming reaction over nickel supported on alumina and lanthana-alumina catalysts. Int. J. Hydrogen Energy 2017, 42, 13039-13060. [CrossRef]

52. Veiga, S.; Faccio, R.; Segobia, D.; Apesteguía, C.; Bussi, J. Hydrogen production by crude glycerol steam reforming over Ni-La-Ti mixed oxide catalysts. Int. J. Hydrogen Energy 2017, 42, 30525-30534. [CrossRef]

53. Jiang, B.; Li, L.; Bian, Z.; Li, Z.; Sun, Y.; Sun, Z.; Tang, D.; Kawi, S.; Dou, B.; Goula, M.A. Chemical looping glycerol reforming for hydrogen production by $\mathrm{Ni}_{\mathrm{Z}} \mathrm{ZrO}_{2}$ nanocomposite oxygen carriers. Int. J. Hydrogen Energy 2018, 43, 13200-13211. [CrossRef]

54. Parlar Karakoc, O.; Kibar, M.E.; Akin, A.N.; Yildiz, M. Nickel-based catalysts for hydrogen production by steam reforming of glycerol. Int. J. Environ. Sci. Technol. 2019, 16, 5117-5124. [CrossRef]

55. Thyssen, V.V.; Sartore, D.M.; Assaf, E.M. Effect of preparation method on the performance of $\mathrm{Ni} / \mathrm{MgOSiO}_{2}$ catalysts for glycerol steam reforming. J. Energy Inst. 2019, 92, 947-958. [CrossRef]

56. Bizkarra, K.; Barrio, V.L.; Gartzia-Rivero, L.; Bañuelos, J.; López-Arbeloa, I.; Cambra, J.F. Hydrogen production from a model bio-oil/bio-glycerol mixture through steam reforming using zeolite 1 supported catalysts. Int. J. Hydrogen Energy 2019, 44, 1492-1504. [CrossRef]

57. Dahdah, E.; Estephane, J.; Gennequin, C.; Aboukaïs, A.; Abi-Aad, E.; Aouad, S. Zirconia supported nickel catalysts for glycerol steam reforming: Effect of zirconia structure on the catalytic performance. Int. J. Hydrogen Energy 2020, 45, 4457-4467. [CrossRef]

58. Shokrollahi Yancheshmeh, M.; Alizadeh Sahraei, O.; Aissaoui, M.; Iliuta, M.C. A novel synthesis of $\mathrm{NiAl}_{2} \mathrm{O}_{4}$ spinel from a Ni-Al mixed-metal alkoxide as a highly efficient catalyst for hydrogen production by glycerol steam reforming. Appl. Catal. B Environ. 2020, 265, 118535. [CrossRef]

59. Menezes, J.P.d.S.Q.; Jácome, F.C.; Manfro, R.L.; Souza, M.M.V.M. Effect of cao addition on nickel catalysts supported on alumina for glycerol steam reforming. Catal. Lett. 2019, 149, 1991-2003. [CrossRef]

60. Adhikari, S.; Fernando, S.D.; To, S.D.F.; Bricka, R.M.; Steele, P.H.; Haryanto, A. Conversion of glycerol to hydrogen via a steam reforming process over nickel catalysts. Energy Fuels 2008, 22, 1220-1226. [CrossRef]

61. Buffoni, I.N.; Pompeo, F.; Santori, G.F.; Nichio, N.N. Nickel catalysts applied in steam reforming of glycerol for hydrogen production. Catal. Commun. 2009, 10, 1656-1660. [CrossRef]

62. Choi, G.Y. Steam Reforming of Glycerol for Hydrogen Production on Ni-Supported Catalysts. Master's Thesis, Chonnam National University, Gwangju, Korea, 2012.

63. Menezes, J.P.d.S.Q.; Manfro, R.L.; Souza, M.M.V.M. Hydrogen production from glycerol steam reforming over nickel catalysts supported on alumina and niobia: Deactivation process, effect of reaction conditions and kinetic modeling. Int. J. Hydrogen Energy 2018, 43, 15064-15082. [CrossRef]

64. Bastan, F.; Kazemeini, M.; Larimi, A.; Maleki, H. Production of renewable hydrogen through aqueous-phase reforming of glycerol over $\mathrm{Ni} / \mathrm{Al}_{2} \mathrm{O}_{3} \mathrm{MgO}$ nano-catalyst. Int. J. Hydrogen Energy 2018, 43, 614-621. [CrossRef]

65. Liu, S.; Yan, Z.; Zhang, Y.; Wang, R.; Luo, S.-Z.; Jing, F.; Chu, W. Carbon nanotubes supported nickel as the highly efficient catalyst for hydrogen production through glycerol steam reforming. ACS Sustain. Chem. Eng. 2018, 6, 14403-14413. [CrossRef]

66. Prasongthum, N.; Xiao, R.; Zhang, H.; Tsubaki, N.; Natewong, P.; Reubroycharoen, P. Highly active and stable $\mathrm{Ni}$ supported on $\mathrm{CNTs}_{-} \mathrm{SiO}_{2}$ fiber catalysts for steam reforming of ethanol. Process. Technol. 2017, 160, 185-195. [CrossRef]

67. Rahman, M.M. H2 production from aqueous-phase reforming of glycerol over Cu-Ni bimetallic catalysts supported on carbon nanotubes. Int. J. Hydrogen Energy 2015, 40, 14833-14844. [CrossRef]

68. Yan, Y.; Miao, J.; Yang, Z.; Xiao, F.-X.; Yang, H.B.; Liu, B.; Yang, Y. Carbon nanotube catalysts: Recent advances in synthesis, characterization and applications. Chem. Soc. Rev. 2015, 44, 3295-3346. [CrossRef]

69. Dal Santo, V.; Gallo, A.; Naldoni, A.; Guidotti, M.; Psaro, R. Bimetallic heterogeneous catalysts for hydrogen production. Catal. Today 2012, 197, 190-205. [CrossRef]

70. Araque, M.; Martínez, T.L.M.; Vargas, J.C.; Centeno, M.A.; Roger, A.C. Effect of the active metals on the selective $\mathrm{H}_{2}$ production in glycerol steam reforming. Appl. Catal. B Environ. 2012, 125, 556-566. [CrossRef]

71. Frusteri, F.; Freni, S.; Chiodo, V.; Spadaro, L.; Di Blasi, O.; Bonura, G.; Cavallaro, S. Steam reforming of bio-ethanol on alkali-doped $\mathrm{Ni} / \mathrm{MgO}$ catalysts: Hydrogen production for MC fuel cell. Appl. Catal. A Gen. 2004, 270, 1-7. [CrossRef] 
72. Iriondo, A.; Barrio, V.L.; Cambra, J.F.; Arias, P.L.; Guemez, M.B.; Navarro, R.M.; Sanchez-Sanchez, M.; Fierro, J.L.G.; Yerga, R.M.N. Hydrogen Production from Glycerol Over Nickel Catalysts Supported on $\mathrm{Al}_{2} \mathrm{O}_{3}$ Modified by Mg, Zr, Ce or La. Top. Catal. 2008, 49, 46-58. [CrossRef]

73. Gallegos-Suarez, E.; Guerrero-Ruiz, A.; Fernández-García, M.; Rodríguez-Ramos, I.; Kubacka, A. Efficient and stable Ni-Ce glycerol reforming catalysts: Chemical imaging using X-ray electron and scanning transmission microscopy. Appl. Catal. B Environ. 2015, 165, 139-148. [CrossRef]

74. Demsash, H.D.; Mohan, R. Steam reforming of glycerol to hydrogen over ceria promoted nickel-alumina catalysts. Int. J. Hydrogen Energy 2016, 41, 22732-22742. [CrossRef]

75. Go, G.-S. Catalytic Activity and Kinetics in Glycerol Steam Reforming over Ni-Based Catalyst. Master's Thesis, Department of Chemical Engineering Graduate School, Chonnam National University, Seoul, Korea, 2016.

76. Hakim, L.; Sari, R.; Daud, W.R.W.; Yaakob, Z.; Ismail, M. Hydrogen production by steam reforming of glycerol over Ni/Ce/Cu hydroxyapatite-supported catalysts. Chem. Pap. 2013, 67, 703-712. [CrossRef]

77. Sánchez, N.; Encinar, J.M.; Nogales-Delgado, S.; González, J.F. Lanthanum Effect on Ni/ $\mathrm{Al}_{2} \mathrm{O}_{3}$ as a Catalyst Applied in Steam Reforming of Glycerol for Hydrogen Production. Processes 2019, 7, 449. [CrossRef]

78. Wang, C.; Dou, B.; Jiang, B.; Song, Y.; Du, B.; Zhang, C.; Wang, K.; Chen, H.; Xu, Y. Sorption-enhanced steam reforming of glycerol on Ni-based multifunctional catalysts. Int. J. Hydrogen Energy 2015, 40, 7037-7044. [CrossRef]

79. Bobadilla, L.; Romero-Sarria, F.; Centeno, M.Á.; Odriozola, J.A. Promoting effect of Sn on supported Ni catalyst during steam reforming of glycerol. Int. J. Hydrogen Energy 2016, 41, 9234-9244. [CrossRef]

80. Oemar, U.; Ang, M.L.; Hidajat, K.; Kawi, S. Enhancing performance of $\mathrm{Ni} / \mathrm{La}_{2} \mathrm{O}_{3}$ catalyst by Sr-modification for steam reforming of toluene as model compound of biomass tar. RSC Adv. 2015, 5, 17834-17842. [CrossRef]

81. Calles, J.; Carrero, A.; Vizcaíno, A.; Garcia-Moreno, L. Hydrogen production by glycerol steam reforming over SBA-15-supported nickel catalysts: Effect of alkaline earth promoters on activity and stability. Catal. Today 2014, 227, 198-206. [CrossRef]

82. Choong, C.K.; Zhong, Z.; Huang, L.; Wang, Z.; Ang, T.P.; Borgna, A.; Lin, J.; Hong, L.; Chen, L. Effect of calcium addition on catalytic ethanol steam reforming of $\mathrm{Ni} / \mathrm{Al}_{2} \mathrm{O}_{3}$ : I. Catalytic stability, electronic properties and coking mechanism. Appl. Catal. A Gen. 2011, 407, 145-154. [CrossRef]

83. Seung-Hoon, K.; Jae-Sun, J.; Eun-Hyeok, Y.; Kwan-Young, L.; Ju, M.D. Hydrogen production by steam reforming of biomass-derived glycerol over Ni-based catalysts. Catal. Today 2014, 228, 145-151. [CrossRef]

84. Kitamura, S.; Su-Enaga, T.; Ikenaga, N.-O.; Miyake, T.; Suzuki, T. Steam Reforming of Glycerin Using Ni-based Catalysts Loaded on $\mathrm{CaO}-\mathrm{ZrO}_{2}$ Solid Solution. Catal. Lett. 2011, 141, 895-905. [CrossRef]

85. Go, Y.-J.; Go, G.-S.; Lee, H.-J.; Moon, D.J.; Park, N.-C.; Kim, Y.C. The relation between carbon deposition and hydrogen production in glycerol steam reforming. Int. J. Hydrogen Energy 2015, 40, 11840-11847. [CrossRef]

86. Huang, Z.-Y.; Xu, C.-H.; Liu, C.-Q.; Xiao, H.-W.; Chen, J.; Zhang, Y.-X.; Lei, Y.-C. Glycerol steam reforming over $\mathrm{Ni} / \gamma-\mathrm{Al}_{2} \mathrm{O}_{3}$ catalysts modified by metal oxides. Korean J. Chem. Eng. 2013, 30, 587-592. [CrossRef]

87. Guerin, S.; Hayden, B.E. $\mathrm{ABO}_{3}$ and $\mathrm{A}_{1}-\mathrm{xCxB1}-\mathrm{yDy}\left(\mathrm{O}_{1}-\mathrm{zEz}\right)_{3}$ : Review of experimental optimisation of thin film perovskites by high-throughput evaporative physical vapour deposition. Chem. Commun. 2019, 55, 10047-10055. [CrossRef] [PubMed]

88. Aman, D.; Radwan, D.; Ebaid, M.; Mikhail, S.; Van Steen, E. Comparing nickel and cobalt perovskites for steam reforming of glycerol. Mol. Catal. 2018, 452, 60-67. [CrossRef]

89. Chen, S.; Wang, H.; Liu, Y. Perovskite La-St-Fe-O (St = Ca, Sr) supported nickel catalysts for steam reforming of ethanol: The effect of the A site substitution. Int. J. Hydrogen Energy 2009, 34, 7995-8005. [CrossRef]

90. Glisenti, A.; Galenda, A.; Natile, M.M. Steam reforming and oxidative steam reforming of methanol and ethanol: The behaviour of $\mathrm{LaCo}_{0.7} \mathrm{Cu}_{0.3} \mathrm{O}_{3}$. Appl. Catal. A Gen. 2013, 453, 102-112. [CrossRef]

91. Pereñíguez, R.; Gonzalez-Delacruz, V.M.; Holgado, J.P.; Caballero, A. Synthesis and characterization of a $\mathrm{LaNiO}_{3}$ perovskite as precursor for methane reforming reactions catalysts. Appl. Catal. B Environ. 2010, 93, 346-353. [CrossRef]

92. Franchini, C.A.; Aranzaez, W.; De Farias, A.M.D.; Pecchi, G.; Fraga, M. Ce-substituted $\mathrm{LaNiO}_{3}$ mixed oxides as catalyst precursors for glycerol steam reforming. Appl. Catal. B Environ. 2014, 147, 193-202. [CrossRef]

93. Xie, S.; Zhang, X.; Tu, Q.; Shi, B.; Cui, Y.; Chen, C. Influence of Preparation Conditions on the Performance of Ni-Based Catalysts for Glycerol Steam Reforming. ACS Omega 2018, 3, 13335-13342. [CrossRef] 
94. Ramesh, S.; Yang, E.-H.; Jung, J.-S.; Moon, D.J. Copper decorated perovskite an efficient catalyst for low temperature hydrogen production by steam reforming of glycerol. Int. J. Hydrogen Energy 2015, 40, 11428-11435. [CrossRef]

95. Ramesh, S.; Venkatesha, N.J. Template Free Synthesis of Ni-Perovskite: An Efficient Catalyst for Hydrogen Production by Steam Reforming of Bioglycerol. ACS Sustain. Chem. Eng. 2017, 5, 1339-1346. [CrossRef]

96. Wu, G.; Li, S.; Zhang, C.; Wang, T.; Gong, J. Glycerol steam reforming over perovskite-derived nickel-based catalysts. Appl. Catal. B Environ. 2014, 144, 277-285. [CrossRef]

97. Dębek, R.; Motak, M.; Duraczynska, D.; Launay, F.; Galvez, M.E.; Grzybek, T.; Da Costa, P. Methane dry reforming over hydrotalcite-derived $\mathrm{Ni}-\mathrm{Mg}$-Al mixed oxides: The influence of Ni content on catalytic activity, selectivity and stability. Catal. Sci. Technol. 2016, 6, 6705-6715. [CrossRef]

98. Dębek, R.; Motak, M.; Gálvez, M.E.; Grzybek, T.; Da Costa, P. Promotion effect of zirconia on Mg(Ni,Al)O mixed oxides derived from hydrotalcites in $\mathrm{CO}_{2}$ methane reforming. Appl. Catal. B Environ. 2018, 223, 36-46. [CrossRef]

99. Nawfal, M.; Gennequin, C.; Labaki, M.; Nsouli, B.; Aboukaïs, A.; Abi-Aad, E. Hydrogen production by methane steam reforming over $\mathrm{Ru}$ supported on $\mathrm{Ni}-\mathrm{Mg}$-Al mixed oxides prepared via hydrotalcite route. Int. J. Hydrogen Energy 2015, 40, 1269-1277. [CrossRef]

100. Ojeda-Niño, O.H.; Gracia, F; Daza, C. Role of Pr on Ni-Mg-Al Mixed Oxides Synthesized by Microwave-Assisted Self-Combustion for Dry Reforming of Methane. Ind. Eng. Chem. Res. 2019, 58, 7909-7921. [CrossRef]

101. Bepari, S.; Basu, S.; Pradhan, N.C.; Dalai, A.K. Steam reforming of ethanol over cerium-promoted Ni-Mg-Al hydrotalcite catalysts. Catal. Today 2017, 291, 47-57. [CrossRef]

102. Coleman, L.J.I.; Epling, W.; Hudgins, R.R.; Croiset, E. Ni/Mg-Al mixed oxide catalyst for the steam reforming of ethanol. Appl. Catal. A Gen. 2009, 363, 52-63. [CrossRef]

103. Li, M.; Wang, X.; Li, S.; Wang, S.; Ma, X. Hydrogen production from ethanol steam reforming over nickel based catalyst derived from Ni/Mg/Al hydrotalcite-like compounds. Int. J. Hydrogen Energy 2010, 35, 6699-6708. [CrossRef]

104. Vizcaíno, A.J.; Lindo, M.; Carrero, A.; Calles, J.A. Hydrogen production by steam reforming of ethanol using Ni catalysts based on ternary mixed oxides prepared by coprecipitation. Int. J. Hydrogen Energy 2012, 37, 1985-1992. [CrossRef]

105. Ferreira, K.A.; Ribeiro, N.F.P.; Souza, M.M.V.M.; Schmal, M. Structural transformation of Cu-Mg-Al mixed oxide catalysts derived from hydrotalcites during shift reaction. Catal. Lett. 2009, 132, 58-63. [CrossRef]

106. Furtado, A.C.; Alonso, C.G.; Cantão, M.P.; Fernandes-Machado, N.R.C. Bimetallic catalysts performance during ethanol steam reforming: Influence of support materials. Int. J. Hydrogen Energy 2009, 34, 7189-7196. [CrossRef]

107. Vizcaíno, A.J.; Carrero, A.; Calles, J.A. Hydrogen production by ethanol steam reforming over Cu-Ni supported catalysts. Int. J. Hydrogen Energy 2007, 32, 1450-1461. [CrossRef]

108. Wang, F.; Li, Y.; Cai, W.; Zhan, E.; Mu, X.; Shen, W. Ethanol steam reforming over Ni and Ni-Cu catalysts. Catal. Today 2009, 146, 31-36. [CrossRef]

109. Manfro, R.L.; Souza, M.M.V.M. Production of renewable hydrogen by glycerol steam reforming using Ni-Cu-Mg-Al mixed oxides obtained from hydrotalcite-like compounds. Catal. Lett. 2014, 144, 867-877. [CrossRef]

110. Dahdah, E.; Aouad, S.; Gennequin, C.; Estephane, J.; Nsouli, B.; Aboukaïs, A.; Abi-Aad, E. Glycerol steam reforming over $\mathrm{Ru}-\mathrm{Mg}$-Al hydrotalcite-derived mixed oxides: Role of the preparation method in catalytic activity. Int. J. Hydrogen Energy 2018, 43, 19864-19872. [CrossRef]

111. De Rezende, S.M.; Franchini, C.A.; Dieuzeide, M.L.; Duarte de Farias, A.M.; Amadeo, N.; Fraga, M.A. Glycerol steam reforming over layered double hydroxide-supported Pt catalysts. Chem. Eng. J. 2015, 272, 108-118. [CrossRef]

112. Hur, E.; Moon, D.J. Steam reforming of glycerol into hydrogen over nano-size Ni-based hydrotalcite-like catalysts. J. Nanosci. Nanotechnol. 2011, 11, 7394-7398. [CrossRef]

(C) 2020 by the authors. Licensee MDPI, Basel, Switzerland. This article is an open access article distributed under the terms and conditions of the Creative Commons Attribution (CC BY) license (http://creativecommons.org/licenses/by/4.0/). 